\title{
Hyperiid amphipod community in the Eastern Tropical Pacific before, during, and after El Niño 1997-1998
}

\author{
Rebeca Gasca ${ }^{1, *}$, Carmen Franco-Gordo ${ }^{2}$, Enrique Godínez-Domínguez ${ }^{2}$, \\ Eduardo Suárez-Morales ${ }^{1}$
}

\author{
${ }^{1}$ El Colegio de la Frontera Sur (ECOSUR), Apdo. Postal 424, Chetumal, Q. Roo 77014, Mexico \\ ${ }^{2}$ Centro Universitario de la Costa Sur (CUCSUR), Universidad de Guadalajara, San Patricio Melaque, Jalisco 48980, Mexico
}

\begin{abstract}
To evaluate the hyperiid community's response to the influence of oceanographic conditions related to 'El Niño' (EN) in the Mexican Tropical Pacific area, zooplankton samples collected over 27 mo between December 1995 and December 1998 were analyzed. The most abundant of the 80 species recorded were Hyperioides sibaginis and Lestrigonus bengalensis. Two different climatic yearly periods were revealed, including one from February to June, related to the strongest flow of the California Current $(\mathrm{CC})$, with cooler $\left(<25^{\circ} \mathrm{C}\right)$ and saltier $(>34.5 \mathrm{psu})$ waters. In this period, hyperiids were more species-rich and diverse, with greater evenness, but had lower abundances. From July to December, the North Equatorial Countercurrent (NECC) was predominant, with warmer waters $\left(>25^{\circ} \mathrm{C}\right)$ and lower salinity $(<34.5 \mathrm{psu})$. $H$. sibaginis and $L$. bengalensis were dominant, particularly in the aftermath of EN (after June 1998). The influence of the Equatorial water during EN favored a greater abundance of warm-water hyperiid families and a greater evenness, particularly during 1998. During EN, higher hyperiid abundance and diversity but also a $30 \%$ increase of species richness and a greater abundance of the dominant species were observed. After the end of EN and for the rest of the sampling period, the oceanographic conditions returned to normality in the area, but the hyperiid community still showed relatively low diversity and high abundance values.
\end{abstract}

KEY WORDS: Zooplankton ecology $\cdot$ Pelagic crustaceans $\cdot$ Diversity

\section{INTRODUCTION}

Hyperiid amphipods are planktonic crustaceans represented by $>250$ species in the world ocean. Attempts have been made to relate the occurrence of hyperiid species with water masses or oceanographic conditions (Bary 1959a,b, Kane 1962, Shulenberger 1977, Siegel-Causey 1982, Gasca 2004, Lavaniegos \& Hereu 2009). Lavaniegos \& Ohman (1999) provided data suggesting that hyperiids are sensitive to largescale climate changes. There are still large neritic and oceanic areas in which basic aspects of this group have not been surveyed; this is true for part of the North and Central Pacific (Vinogradov 1999). Information about the hyperiids from the Eastern Pacific region has been mainly taxonomic (Brusca \& Hendrickx 2005, Gasca 2009a, Gasca et al. 2010), and none of the ecological contributions (Brusca 1967, Gasca \& Haddock 2004, Lavaniegos \& Hereu 2009) have been related to EN conditions.

It has been documented that EN has important effects on the zooplankton communities of the Pacific Ocean (Fiedler 2002, Badán-Dangón 2003). The influence of EN 1997-98 on the marine biota has been studied in different sectors of the California Current (CC), such as off California (Marinovic et al. 
2002, Peterson \& Keister 2002) and Baja California (Lavaniegos et al. 2002, 2003, Palomares-García et al. 2003, Hereu et al. 2006), but its influence on the hyperiid community of the Eastern Tropical Pacific remains unstudied.

We analyze the inter-annual variability of the hyperiid community of the Mexican Pacific central coast based on zooplankton samples collected during 27 mo between December 1995 and December 1998, a period including the influence of EN 1997-98.

The study area is located off the central Mexican coast in the Eastern Tropical Pacific (ETP) region (Fig. 1). It is part of the Central American Coastal Province (Longhurst 2006) and bounded by the north and south equatorial fronts. The continental shelf along this coast is relatively narrow (7 to $10 \mathrm{~km}$ ) (Filonov \& Tereshchenko 2000).

The latitudinal position of the transition zone, where the CC joins the North Equatorial Countercurrent (NECC) off the surveyed area, varies depending on the strength of winds and currents (Kessler 2006). In winter, when the CC is more intense, the transitional area is located farther south, whereas in the summer, when the NECC is more intense, the transition zone moves to the north. Hence, 2 distinct climatic periods (CPs) can be defined, one influenced by cooler waters of the $\mathrm{CC}$ and the second influenced by the NECC. In winter and spring (February to June), the local conditions are characterized by the absence of the NECC and the influence of the CC. The water is relatively cooler $\left(>25^{\circ} \mathrm{C}\right)$ and with low salinity (34.5 psu); it has a south-southeast flow far from the coast north of $23^{\circ} \mathrm{N}$ (Aguirre-Gómez et al. 2003). The direct influence of the CC in the surveyed area has not been proven, but the regional oceanographic dynamics are characterized by the CC-NECC system, so we used this regional frame as our main reference (Kessler 2006, Trasviña \& Barton 2008).

Typical ETP surface waters (50-75 $\mathrm{m})$ show 2 seasonal conditions: from June to December, Pacific Tropical Surface Water (PTSW) occurs with salinities <34 psu and temperatures $>25^{\circ} \mathrm{C}$, whereas Pacific Equatorial Surface Water (PESW) with salinities $>34 \mathrm{psu}$ and temperatures $<25^{\circ} \mathrm{C}$ occurs from January to May and June. Under this layer (75-200 m) lies the Pacific Equatorial Water (PEW)
(Trasviña et al. 1999, Filonov \& Tereshchenko 2010) (Fig. 2).

In September, large volumes of equatorial water affected the zone, and by December 1997, they comprised the upper $70 \mathrm{~m}$. The maximum intensity of EN occurred in January 1998 when equatorial waters occupied the upper $80 \mathrm{~m}$ layer $\left(27.5^{\circ} \mathrm{C}, 34 \mathrm{psu}\right)$. By May 1998, the hydrographic structure began to return to the conditions that existed in 1996 (Fig. 2) (Trasviña et al. 1999, Filonov \& Tereshchenko 2010).

\section{MATERIALS AND METHODS}

The hydrographic data used in this work, including local profiles of temperature and salinity during the study period, were described and analyzed by Filonov \& Tereshchenko (2000, 2010). The 269 zooplankton samples analyzed were obtained at 12 sites sampled monthly between December 1995 and December 1998 (27 mo). The sampling transects are located on the continental shelf and separated from the coastline by a distance of $3 \mathrm{~km}$ (inshore transect) and $4.5 \mathrm{~km}$ (offshore transect) (Fig. 1).

The sampling was performed on board the R/V 'BIP-V', following Smith \& Richardson (1977); all samples were obtained at nighttime using oblique and semicircular trawls at depths between 30 and $115 \mathrm{~m}$ to the surface, depending on the bottom depth. A bongo net $(0.6 \mathrm{~m}$ mouth diameter, $0.505 \mathrm{~mm}$ mesh opening, with a digital flowmeter) was used to obtain the zooplankton samples, which were fixed and preserved with $4 \%$ formalde-

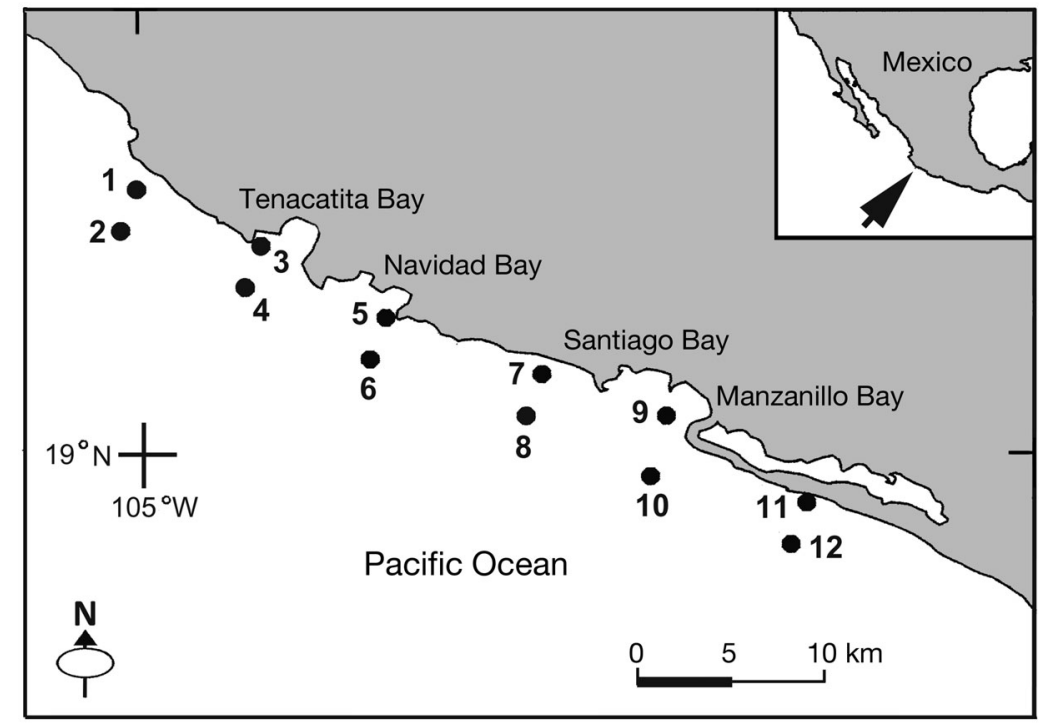

Fig. 1. Study area and sampling stations off the central coast of the Mexican Pacific 


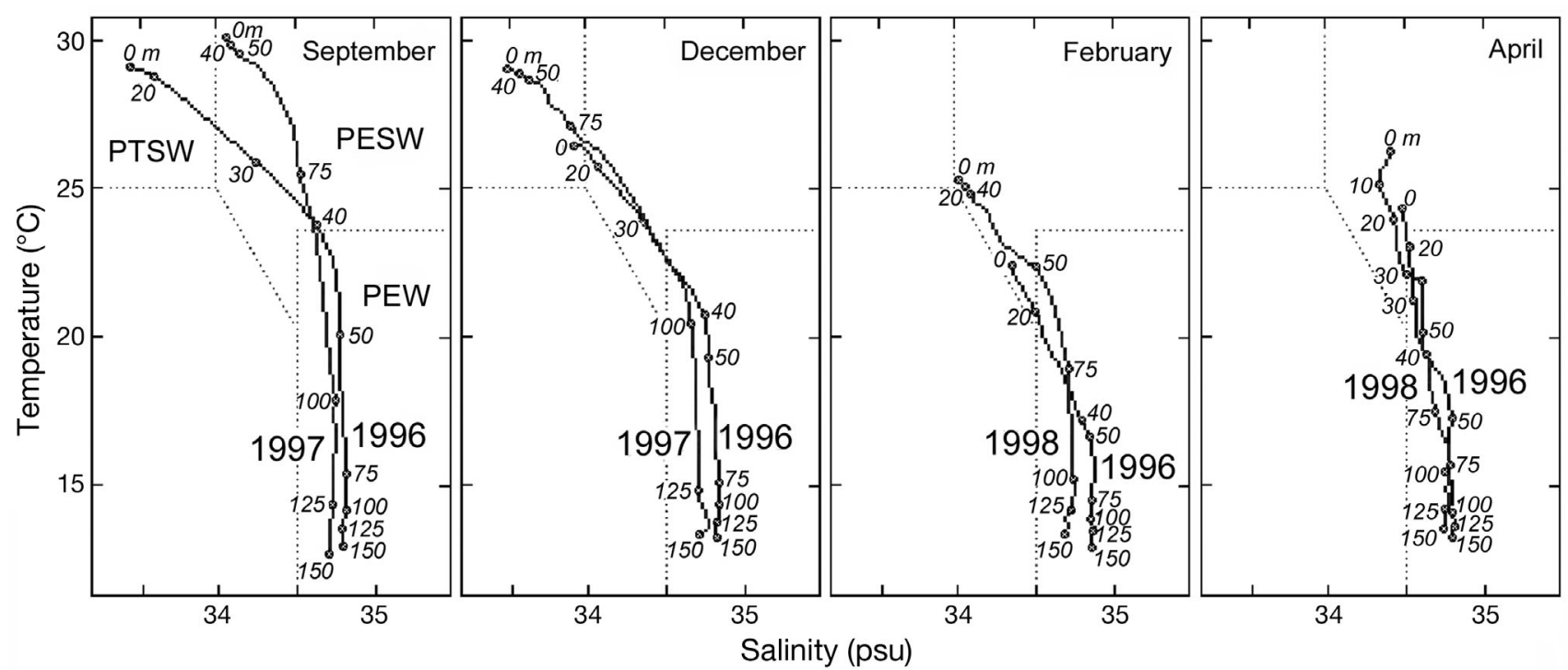

Fig. 2. Monthly average temperature and salinity. Dotted lines outline main water masses. PTSW: Pacific Tropical Surface Water, PESW: Pacific Equatorial Surface Water, PEW: Pacific Equatorial Water (after Filonov \& Tereshchenko 2010)

hyde buffered with sodium borate. Hyperiid amphipods were sorted from the original samples and transferred to a solution of distilled water (95\%) with propylene glycol $(4.5 \%)$ and propylene phenoxetol $(0.5 \%)$ for long-term storage.

Hyperiids were identified following Vinogradov et al. (1996), Harbison \& Madin (1976), Shih (1991), and Zeidler (2003, 2004a,b, 2006). Abundance was standardized to ind. $1000 \mathrm{~m}^{-3}$. June and December were removed from the $\mathrm{CP}$ analyses of both the CC (January to May) and NECC (July to November) periods. An analysis of variance (ANOVA) was performed with the total hyperiid abundance $\left(\log _{10}[\mathrm{x}+1]\right)$ considering (1) the CP surveyed, (2) inshore and offshore stations, (3) data collection pre-EN (before July 1997), during EN (July 1997 to April 1998) and postEN (the remaining stations), and (4) EN and non-EN conditions (EN1: July 1997 to April 1998, EN0: the remaining samples). These analyses were performed using the Brodgar multivariate analysis and multivariate time series analysis (version 2). When necessary, we conducted a post-hoc test for multiple comparisons (Tukey-Kramer method) to determine if averages were statistically different (Sokal \& Rohlf 1995).

The hyperiid diversity analysis by $\mathrm{CP}$ was performed in terms of species richness, evenness, and diversity (Shannon index). Rarefaction curves (Gotelli \& Graves 1996) were produced for each of these parameters and were estimated using the probability of interspecific encounter (PIE) (Hurlbert 1971). This procedure provides comparative estimates, regard- less of differences in the sample sizes of the groups compared. Abundance levels for simulation were established using the sample with the lowest values of abundance to allow comparisons of sample groups. The ECOSIM program was used to calculate diversity indices (Gotelli \& Entsminger 2009), which uses the Monte Carlo method and 1000 replicates in the simulation for each estimate. Samples are randomly selected without replacement, and this procedure is repeated 1000 times to estimate an average value and $95 \%$ confidence interval for various levels of abundance.

To determine the response of the hyperiid community associations to the intra-annual (CP) and interannual (EN) temporal and spatial (distance from shore) variation, we performed a similarity analysis (ANOSIM) to statistically evaluate the differences among the groups examined (Clarke \& Warwick 2001). A similarity percentage analysis (SIMPER) (Clarke 1993) allowed the detection of groups of species that typify both the similarity (within groups) and the dissimilarity (between groups). Analyses were performed using the PRIMER 6 software, using the Bray Curtis index with untransformed data (Clarke \& Gorley 2006).

A non-metric multidimensional scaling (NMDS), based on the standardized abundances of all species, and the Bray Curtis similarity index with zero adjustment (Clarke et al. 2006) was used to explore the hypothesis that seasonality, EN, and distance from coast shape the local hyperiid associations. We also performed a direct gradient redundancy analysis. 
This method is the canonical version of a principal component analysis (Leps \& Smilauer 2007) and considers a $\log _{10}$ transformed data matrix of the total abundance of species/samples and the multivariate El Niño index (MEI) (Wolter \& Timlin 1998). We performed a significance analysis of management models using a permutation test (Monte Carlo method) to evaluate the independence between the matrices of species abundance and environmental variables (Leps \& Smilauer 2007). The redundancy analysis was performed using CONOCO (ter Braak \& Smilauer 1998).

\section{RESULTS}

\section{Species composition}

From the taxonomic analysis of the 269 hyperiid samples examined, 80 species were identified, representing 38 genera, 16 families, and 2 suborders. The list of species along with the sequence in which each of them appeared per semester is shown in Table 1. Up to $24(30 \%)$ of the 80 species occurred after July 1997, and 19 occurred in the last year of sampling, during conditions associated with EN.

Table 1. Hyperiid species recorded. First occurrence (FO) by sampling semester I (December 1995 to June 1996), II (July to December 1996), III (January to June 1997), IV (July to December 1997), V (January to June 1998), and VI (July to December 1998); overall numerical abundance (Total $\sum_{i}$ total number of individuals in all samples), average abundance (ind. $1000 \mathrm{~m}^{-3}$ over all samples), frequency ( $\mathrm{F}$; o f samples in which species occurred), and geometric mean (GM) of species abundance in all samples

\begin{tabular}{|c|c|c|c|c|c|c|c|c|c|c|c|}
\hline & $\mathrm{FO}$ & Total $\Sigma$ & Average & $\mathrm{F}(\%)$ & GM & & $\mathrm{FO}$ & Total $\Sigma$ & Average & $F(\%)$ & GM \\
\hline Hyperioides sibaginis & I & 187757 & 697.98 & 83.33 & 106.66 & Lycaea bovalloides & I & 193 & 0.72 & 4.07 & 1.12 \\
\hline Lestrigonus bengalensis & I & 41167 & 153.04 & 76.30 & 30.68 & Amphithyrus muratus & III & 190 & 0.70 & 5.19 & 1.14 \\
\hline Lestrigonus schizogeneios & I & 16068 & 59.73 & 42.96 & 4.03 & Lycaea serrata & $\mathrm{I}$ & 173 & 0.64 & 2.22 & 1.06 \\
\hline Tetrathyrus forcipatus & I & 4887 & 18.17 & 42.96 & 3.89 & Lycaea pachypoda & II & 163 & 0.61 & 2.22 & 1.07 \\
\hline Lestrigonus shoemakeri & I & 3886 & 14.45 & 40.37 & 3.64 & Dairella californica & I & 155 & 0.57 & 3.70 & 1.1 \\
\hline Parascelus edwardsi & I & 3685 & 13.70 & 49.63 & 4.54 & Themistella fusca & I & 135 & 0.50 & 4.44 & 1.11 \\
\hline Lycaeopsis zamboangae & I & 2965 & 11.02 & 44.07 & 3.72 & Platyscelus crustulatus & I & 131 & 0.49 & 4.44 & 1.11 \\
\hline Paralycaea hoylei & I & 2225 & 8.27 & 27.04 & 2.33 & Oxycepalus latirostris & $\mathrm{V}$ & 113 & 0.42 & 3.70 & 1.09 \\
\hline Euthamneus rostratus & I & 2210 & 8.22 & 11.85 & 1.46 & Phronima bowmani & I & 105 & 0.39 & 3.33 & 1.09 \\
\hline Hyperietta vosseleri & I & 2003 & 7.45 & 20.00 & 1.84 & Vibilia chuni & I & 103 & 0.38 & 3.70 & 1.09 \\
\hline Oxycephalus clausi & I & 1810 & 6.73 & 28.52 & 2.31 & Paraphronima gracilis & III & 98 & 0.37 & 2.59 & 1.07 \\
\hline Lestrigonus macrophthalmus & III & 1722 & 6.40 & 20.00 & 1.93 & Hyperietta luzoni & III & 93 & 0.35 & 2.22 & 1.06 \\
\hline Brachyscelus crusculum & I & 1719 & 6.39 & 32.59 & 2.49 & Vibilia viatrix & $\mathrm{V}$ & 92 & 0.34 & 1.85 & 1.05 \\
\hline Vibilia longicarpus & III & 1694 & 6.30 & 5.93 & 1.28 & Streetsia mindanaonis & I & 62 & 0.23 & 1.85 & 1.05 \\
\hline Simorhynchotus antennarius & $\mathrm{I}$ & 1634 & 6.07 & 37.41 & 2.77 & Lestrigonus crucipes & III & 59 & 0.22 & 1.85 & 1.05 \\
\hline Lycaea vincentii & I & 944 & 3.51 & 13.70 & 1.25 & Phronima dunbari & I & 58 & 0.22 & 1.48 & 1.04 \\
\hline Lycaea pulex & I & 867 & 3.22 & 17.04 & 1.61 & Leptocotis tenuirostris & I & 43 & 0.16 & 1.48 & 1.04 \\
\hline Lycaeopsis themistoides & I & 845 & 3.14 & 17.41 & 1.63 & Paralycaea gracilis & IV & 39 & 0.15 & 1.11 & 1.03 \\
\hline Anchylomera blossevillei & IV & 836 & 3.11 & 11.48 & 1.42 & Phronima bucephala & III & 38 & 0.14 & 1.48 & 1.04 \\
\hline Amphithyrus sculpturatus & I & 614 & 2.28 & 17.41 & 1.56 & Phronima sedentaria & $\mathrm{V}$ & 37 & 0.14 & 1.48 & 1.03 \\
\hline Phronima atlantica & III & 572 & 2.13 & 11.11 & 1.37 & Thyropus sphaeroma & IV & 34 & 0.13 & 1.11 & 1.03 \\
\hline Platyscelus serratulus & I & 550 & 2.05 & 14.44 & 1.45 & Eupronoe maculata & $\mathrm{V}$ & 32 & 0.12 & 0.74 & 1.02 \\
\hline Eupronoe armata & IV & 523 & 1.94 & 12.22 & 1.38 & Vibilia borealis & II & 31 & 0.12 & 0.74 & 1.02 \\
\hline Lestrigonus latissimus & I & 467 & 1.74 & 10.00 & 1.31 & Lycaea lilia & $\mathrm{V}$ & 30 & 0.11 & 0.37 & 1.01 \\
\hline Amphithyrus bispinosus & $\mathrm{I}$ & 451 & 1.68 & 12.22 & 1.35 & Primno evansi & $\mathrm{V}$ & 28 & 0.10 & 1.11 & 1.03 \\
\hline Hyperoche martinezi & $\mathrm{V}$ & 413 & 1.54 & 2.59 & 1.1 & Eupronoe minuta & $\mathrm{V}$ & 25 & 0.09 & 1.11 & 1.03 \\
\hline Phronimella elongata & IV & 381 & 1.42 & 5.56 & 1.18 & Primno brevidens & $\mathrm{V}$ & 25 & 0.09 & 0.74 & 1.02 \\
\hline Vibilia armata & I & 380 & 1.41 & 5.93 & 1.18 & Amphithyrus glaber & $\mathrm{V}$ & 20 & 0.07 & 0.74 & 1.02 \\
\hline Phrosina semilunata & III & 368 & 1.37 & 8.15 & 1.25 & Tryphana malmi & $\mathrm{V}$ & 19 & 0.07 & 0.74 & 1.02 \\
\hline Phronimopsis spinifera & I & 351 & 1.30 & 6.67 & 1.2 & Rhabdosoma minor & I & 18 & 0.07 & 0.74 & 1.02 \\
\hline Lycaea bajensis & I & 328 & 1.22 & 4.44 & 1.15 & Hyperioides longipes & VI & 18 & 0.07 & 0.74 & 1.02 \\
\hline Lycaea bovalli & I & 273 & 1.01 & 5.93 & 1.18 & Phronima solitaria & $\mathrm{V}$ & 16 & 0.06 & 0.74 & 1.02 \\
\hline Brachyscelus rapacoides & I & 269 & 1.00 & 5.19 & 1.15 & Eupronoe laticarpa & $\mathrm{V}$ & 14 & 0.05 & 0.37 & 1.01 \\
\hline Glossocephalus milneedwards & & 245 & 0.91 & 6.67 & 1.19 & Platyscelus ovoides & $\mathrm{V}$ & 12 & 0.05 & 0.37 & 1.01 \\
\hline Brachyscelus globiceps & I & 243 & 0.91 & 4.07 & 1.12 & Streetsia porcella & IV & 12 & 0.05 & 0.37 & 1.01 \\
\hline Vibilia propinqua & I & 231 & 0.86 & 2.59 & 1.08 & Cranocephalus scleroticus & I & 12 & 0.04 & 0.37 & 1.01 \\
\hline Scina marginata & I & 230 & 0.86 & 1.48 & 1.06 & Oxycephalus piscator & $\mathrm{V}$ & 11 & 0.04 & 0.37 & 1.01 \\
\hline Hyperietta stephenseni & III & 225 & 0.84 & 4.44 & 1.13 & Paratyphis parvus & I & 9 & 0.03 & 0.37 & 1.01 \\
\hline Rhabdosoma whitei & I & 221 & 0.82 & 6.67 & 1.18 & Hemityphis tenuimanus & $\mathrm{V}$ & 7 & 0.03 & 0.37 & 1.01 \\
\hline Parapronoe parva & I & 208 & 0.77 & 7.04 & 1.19 & Schizoscelus ornatus & $\mathrm{V}$ & 7 & 0.03 & 0.37 & 1.01 \\
\hline
\end{tabular}




\section{Analysis of abundance}

The most abundant species were Hyperioides sibaginis, (65.1\%), Lestrigonus bengalensis (14.27\%), L. schizogeneios $(5.57 \%)$, Tetrathyrus forcipatus $(1.69 \%)$, L. shoemakeri (1.35\%), Parascelus edwardsi $(1.28 \%)$, Lycaeopsis zamboangae $(1.03 \%)$, Euthamneus rostratus $(0.77 \%)$, Paralycaea hoylei $(0.77 \%)$, Hyperietta vosseleri $(0.7 \%)$, and Oxycephalus clausi $(0.63 \%)$ (Table 1). Eight species were found in $>100$ of the 269 samples: $H$. sibaginis (in 225 samples), $L$. bengalensis (206), P. edwardsi (134), L. zamboangae (119), L. schizogeneios (116), T. forcipatus (116), L. shoemakeri (109), and Simorhynchotus antennarius (101). Of the 21 species that appeared in $\leq 3$ stations, only 4 (Cranocephalus scleroticus, Paratyphis parvus, Rhabdosoma minor, and Vibilia borealis) occurred before July 1997, whereas the other 17 species were collected after this month. The most abundant species at inshore stations were $H$. sibaginis, L. bengalensis, L. schizogeneios, T. forcipatus, E. rostratus, and $P$. hoylei.

The overall average abundance of hyperiids was 1070 individuals (ind.) $1000 \mathrm{~m}^{-3}$. Monthly abundances $\left(\log _{10}[x+1]\right)$ were highly variable and distinct from one another $(F=88.19, \mathrm{p}<0.001)$. The abundance values were $>1700$ ind. $1000 \mathrm{~m}^{-3}$ in July 1996, February, July, and December 1997, and January,
Table 2. Results from the ANOVA for (a) the studied climate periods; (b) inshore and offshore stations; (c) data from preEN (before July 1997), during EN, and post-EN; (d) during EN1 (July 1997 to April 1998) and EN0 (remaining data)

\begin{tabular}{|lcccr|}
\hline $\begin{array}{l}\text { Abundance } \\
\left(\log _{10}\right)\end{array}$ & df & $F$ & $p$ & \multicolumn{1}{c}{$\begin{array}{c}\text { SS } \\
\text { (resid) }\end{array}$} \\
\hline (a) CP & 205 & 26.210 & $<0.001$ & 59.179 \\
(b) Inshore/offshore & 267 & 12.092 & $<0.001$ & 116.257 \\
$\begin{array}{c}\text { (c) Pre-, post-, } \\
\text { during EN }\end{array}$ & 267 & 52 & $<0.001$ & 87.319 \\
(d) EN0, EN1 & 267 & 22.382 & $<0.001$ & 112.123 \\
\hline
\end{tabular}

June, July, and September 1998. Abundances <200 ind. $1000 \mathrm{~m}^{-3}$ were recorded in February, April, May, November, and December 1996. The average annual abundance progressively increased from 502 ind. $1000 \mathrm{~m}^{-3}$ during 1995 and 1996 to 1176 in 1997 and 1502 ind. $1000 \mathrm{~m}^{-3}$ in 1998.

The average abundance also increased throughout the CP in each year (1995 to 1998), being 86 ind. $1000 \mathrm{~m}^{-3}$ in $96 \mathrm{CC}, 320$ ind. $1000 \mathrm{~m}^{-3}$ in $96 \mathrm{NE}, 823$ in $97 \mathrm{CC}, 1142$ in $97 \mathrm{NE}, 1319$ in $98 \mathrm{CC}$, and 1664 in 98NE. In general, the differences among the CP were significant (Table 2, Fig. 3a). Hyperiids were more abundant inshore (1432 ind. $1000 \mathrm{~m}^{-3}$ ) than offshore (736 ind. $1000 \mathrm{~m}^{-3}$ ) (Table 2, Fig. 3b). They were more abundant in the post-EN (1524 ind. $1000 \mathrm{~m}^{-3}$ )
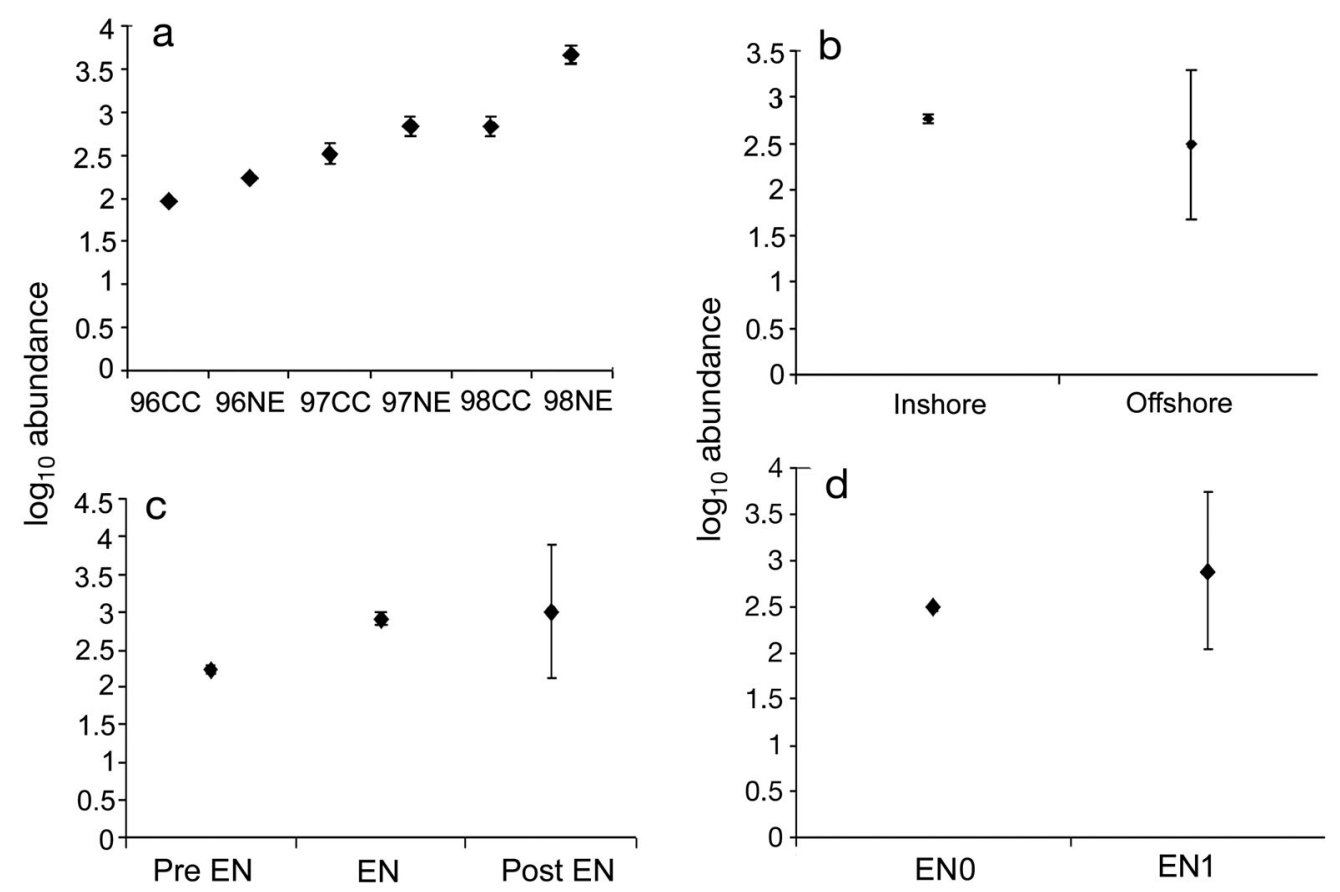

Fig. 3. Total hyperiid abundances $\left(\log _{10}[x+1]\right)$ obtained for (a) the surveyed climatic periods (CPs), (b) inshore and offshore stations, (c) data from pre-EN (before July 1997), EN, and post-EN and (d) during EN1 (July 1997 to April 1998) and EN0 (remaining data). Data are averages (dots) and confidence intervals 95\% (bars). CPs are named by year and current (e.g. 96CC is the period of 1996 dominated by the California Current) 


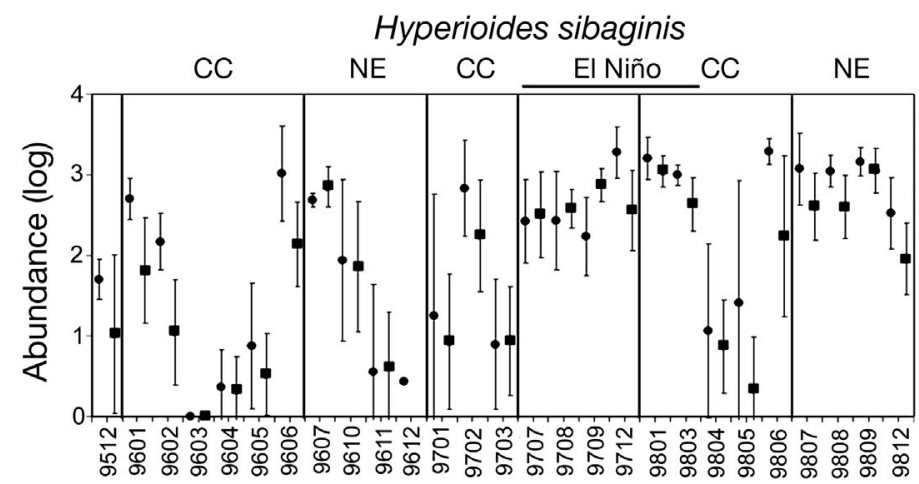

Lestrigonus schizogeneios

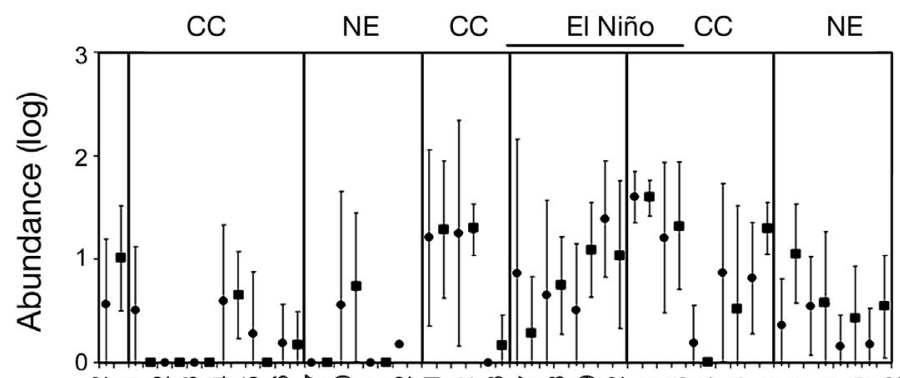

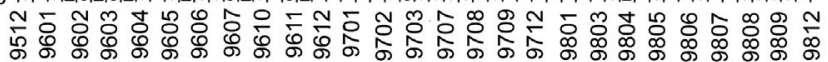

\section{Lestrigonus shoemakeri}

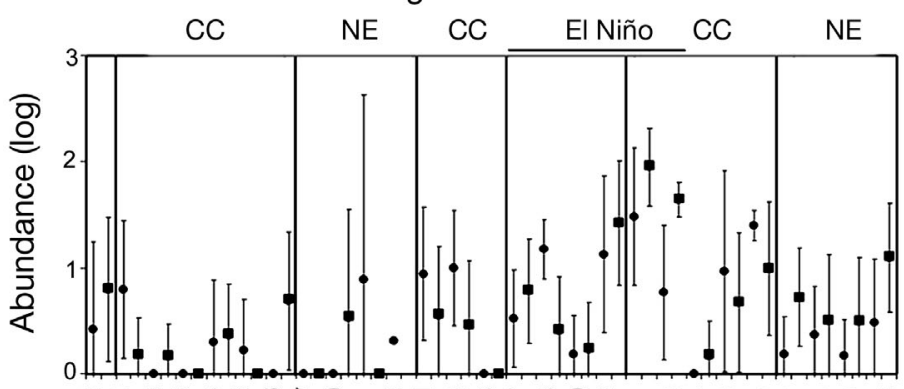

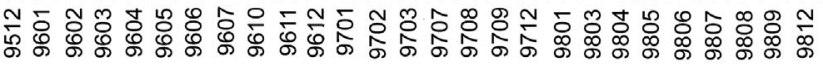

Lycaeopsis zamboangae

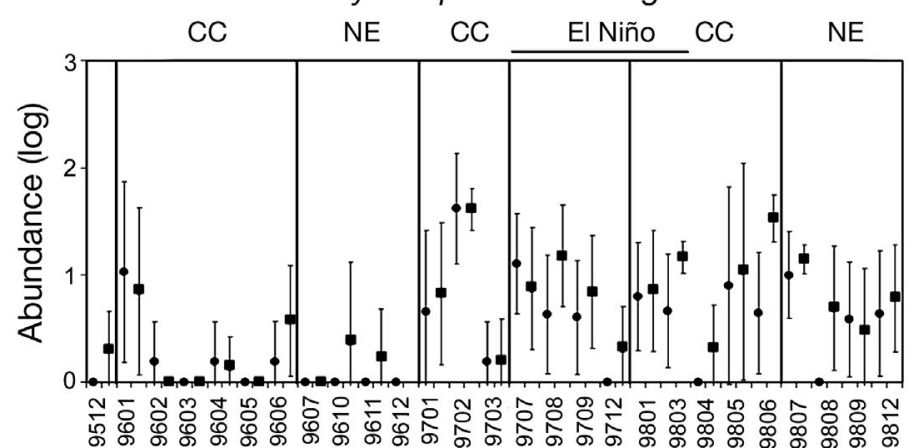

Lestrigonus bengalensis

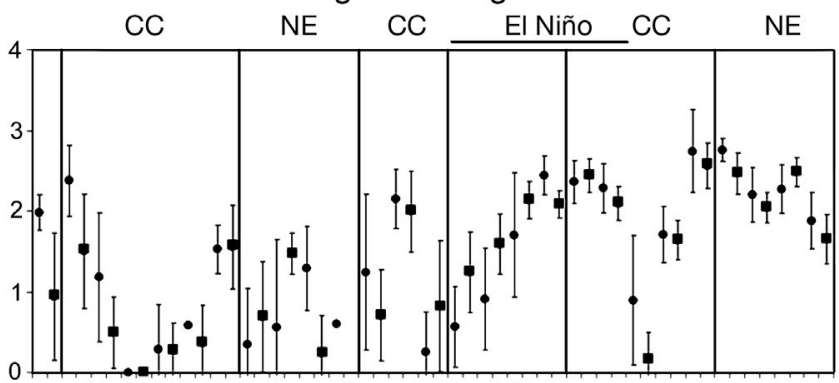

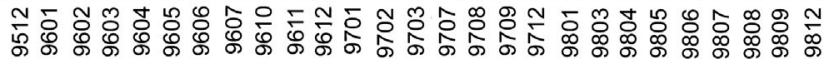

Tetrathyrus forcipatus

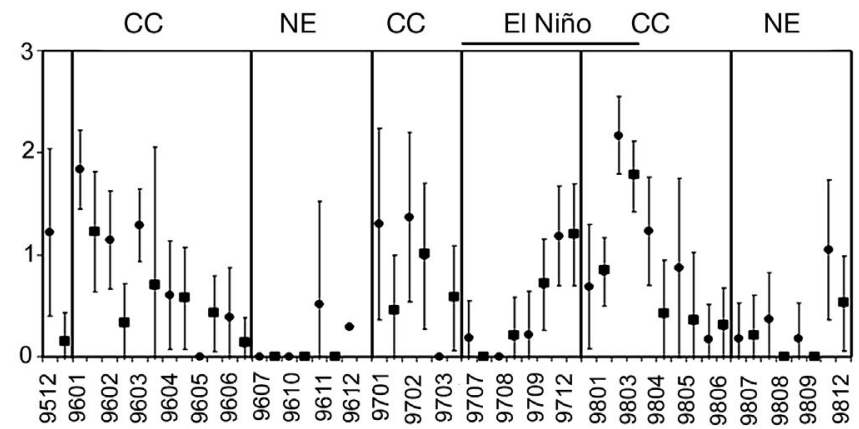

Parascelus edwardsi

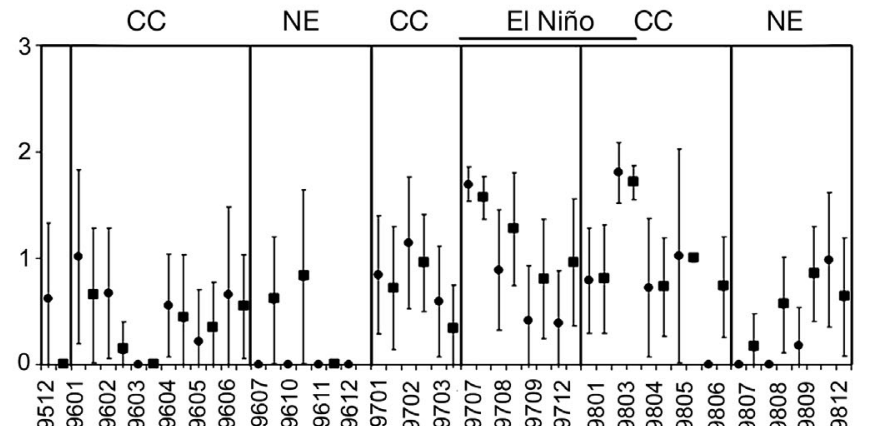

Hyperietta vosseleri

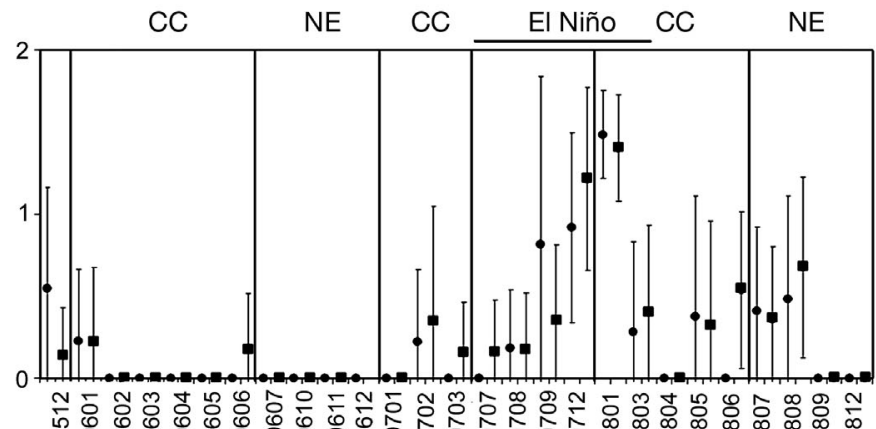

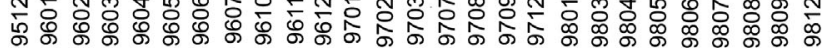

Date (year \& month)

Fig. 4. Monthly average abundances $\left(\log _{10}[\mathrm{x}+1]\right)$ and $95 \%$ confidence interval of total numbers of Hyperioides sibaginis, Lestrigonus bengalensis, Lestrigonus schizogeneios, Tetrathyrus forcipatus, Lestrigonus shoemakeri, Parascelus edwardsi, Lycaeopsis zamboangae, and Hyperietta vosseleri in the studied area. @: inshore stations, $\mathbf{\square}$ : offshore stations 
period than before (594 ind. $1000 \mathrm{~m}^{-3}$ ) or during the EN (1432 ind. $1000 \mathrm{~m}^{-3}$ ) (Table 2, Fig. 3c). Furthermore, they were also more abundant during the influence of EN than in all other samples (914 ind. $1000 \mathrm{~m}^{-3}$ ) (Table 2, Fig. 3d).

The most abundant species were more abundant inshore than offshore. Hyperioides sibaginis had an average of 948 ind. $1000 \mathrm{~m}^{-3}$ inshore and 457 ind. $1000 \mathrm{~m}^{-3}$ at offshore stations; the same pattern was observed in Lestrigonus bengalensis (191 vs. 117 ind. $1000 \mathrm{~m}^{-3}$ ), L. schizogeneios (107 vs. 13), Tetrathyrus forcipatus (26 vs. 11), and Parascelus edwardsi (15 vs. 12).

A significant correlation $(F=4.117, \mathrm{p}<0.1)$ was obtained between the monthly geometric mean (GM) of hyperiid abundance and Niño Index 3.4 (SST index for the Niño 3.4 Region; Trenberth 1997). We also observed a significant relationship between the monthly GM of Hyperioides sibaginis and the same EN index $(F=2.094, \mathrm{p}=0.163)$ but not for the GM of the other most abundant species, Lestrigonus bengalensis, $(F=0.177, \mathrm{p}=0.6775)$. The monthly abundances of hyperiid species with average densities $>10$ ind. $1000 \mathrm{~m}^{-3}$ were plotted to observe the temporal variations (Fig. 4).

\section{Analysis of diversity}

\section{Species richness}

The number of species recorded ranged from 3 (March and December 1996) to 48 (January 1998). We observed fewer species in the first $2 \mathrm{yr}$ of sampling (Fig. 5). Results from the rarefaction curves revealed that the largest expected number of species corresponded to the $\mathrm{CC}$ periods of each year, with no differences among them. During NECC periods, the expected number of species was consistently lower than in the CC (cold) periods (Fig. 6a).

The expected number of species was higher offshore than inshore (Fig. 6b). It tended to be higher during EN, followed by the pre-EN and post-EN periods (Fig. 6c); no differences were found between EN1 and the rest of the samples (EN0) (Fig. 6d). Up to 68 species were recorded at inshore stations vs. 77 offshore. Only Platyscelus ovoides, Oxycephalus piscator, and Cranocephalus scleroticus were not recorded at inshore stations.

\section{Shannon diversity}

The rarefaction curve analysis of diversity (Shannon) revealed that $\mathrm{CC}$ periods were more diverse than the NE periods; the 1997 NE CP was intermediate between the warm and cold CP (Fig. 7a). Diversity at inshore stations was higher than offshore (Fig. 7b); diversity was higher during EN, followed by pre-EN and by post-EN periods, with a very low diversity (Fig. 7c). Diversity was higher during EN1 than in the rest of the samples (EN0) (Fig. 7d).

\section{Evenness}

A higher number of samples exhibited evenness values $>0.5$ (171 vs. 98), i.e. there were no markedly dominant species. Evenness values diverged from the pattern observed for diversity and richness

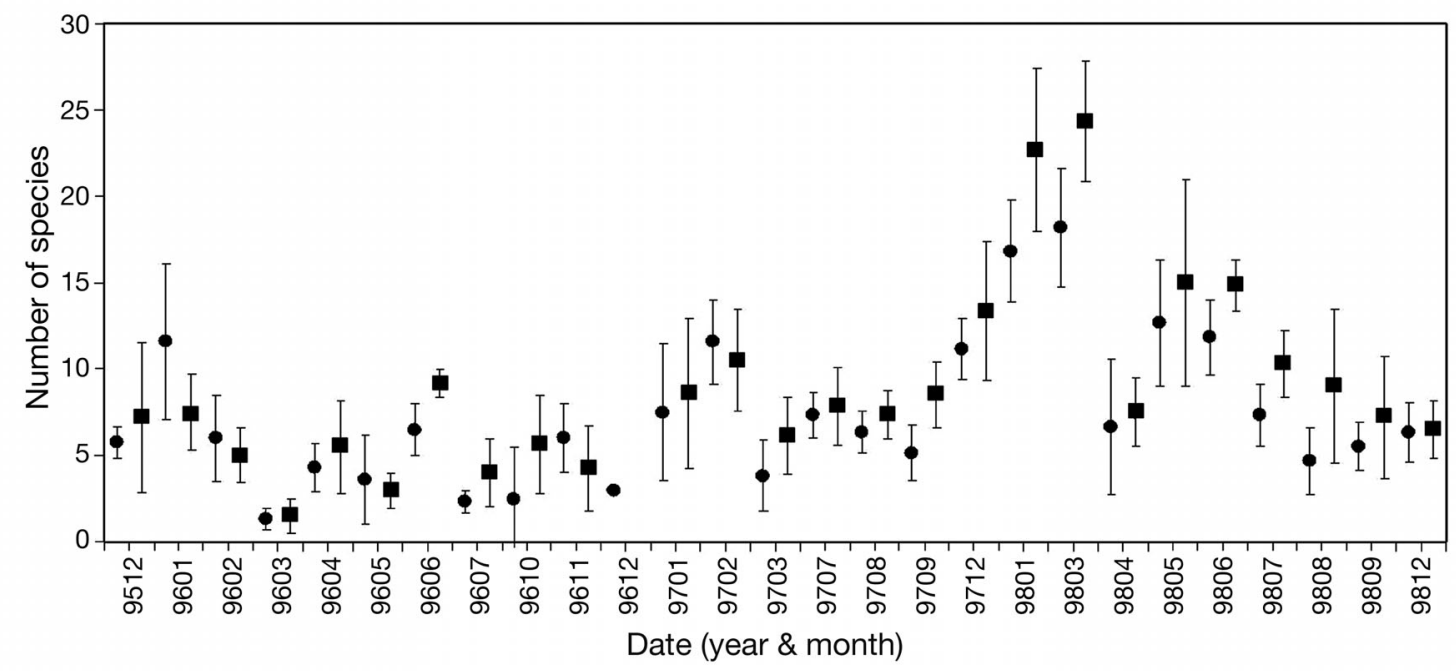

Fig. 5. Average number of species (95\% confidence interval) in the Mexican Central Pacific from 1995 to 1998 at inshore (•) and offshore (ם) stations 


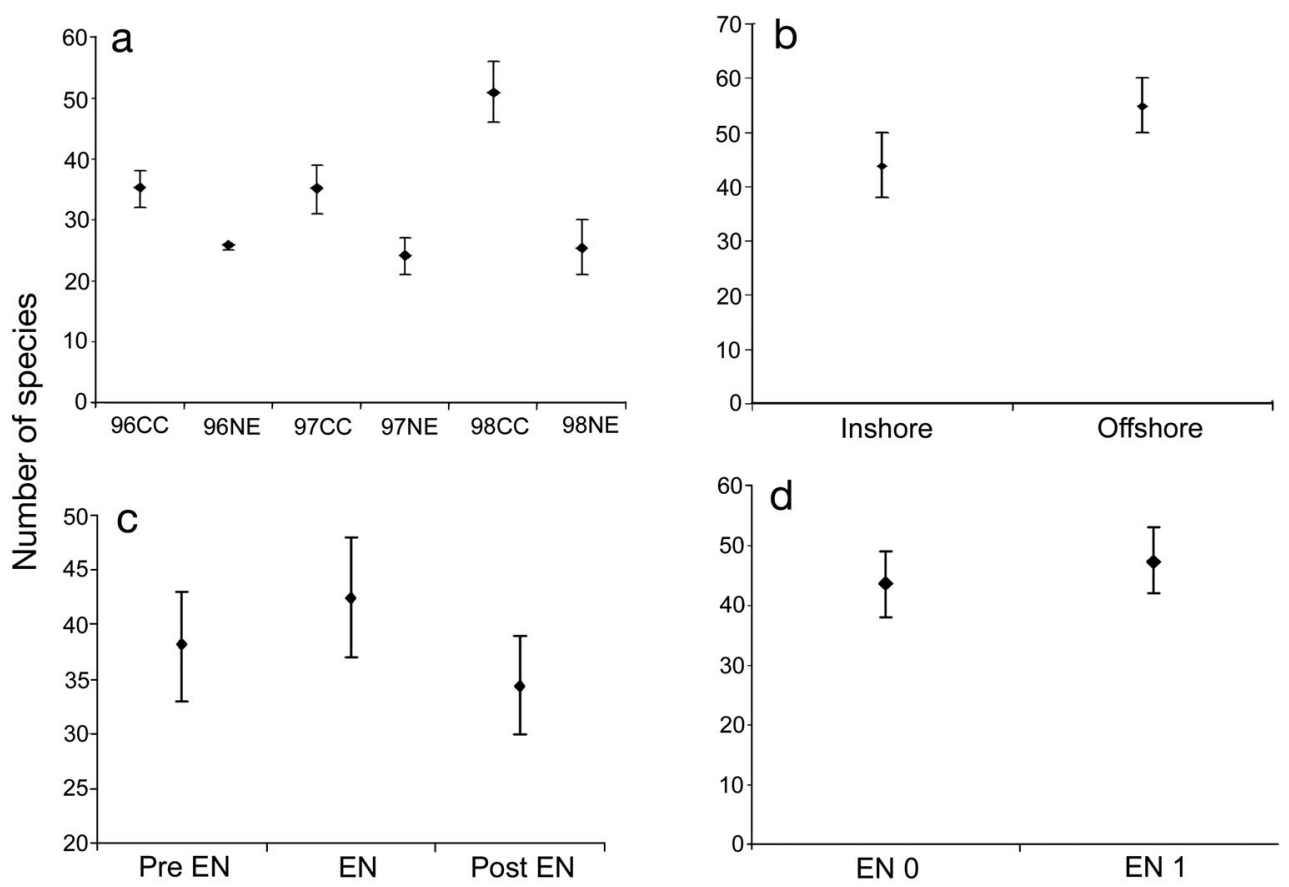

Fig. 6. Species richness based on rarefaction curves. (a) Surveyed CPs; (b) inshore and offshore stations; (c) data from pre-EN (before July 1997), EN, and post-EN; (d) during EN 1 (July 1997 to April 1998) and EN 0 (remaining data)

(Fig. 8a). Higher values of evenness were found during the influence of EN and were similar to those of 96CC. Extreme values of this index were observed in 1996. A reverse tendency occurred in 1997: during the $\mathrm{NE}$, values were higher than during the $\mathrm{CC}$, and evenness was uniform between $97 \mathrm{CC}$ and 98NE. Dominance was lower offshore (Fig. 8b), and greater evenness values occurred during the pre-EN than in the post-EN period (Fig. 8c). A high evenness was found during EN1 than during EN0 (Fig. 8d).
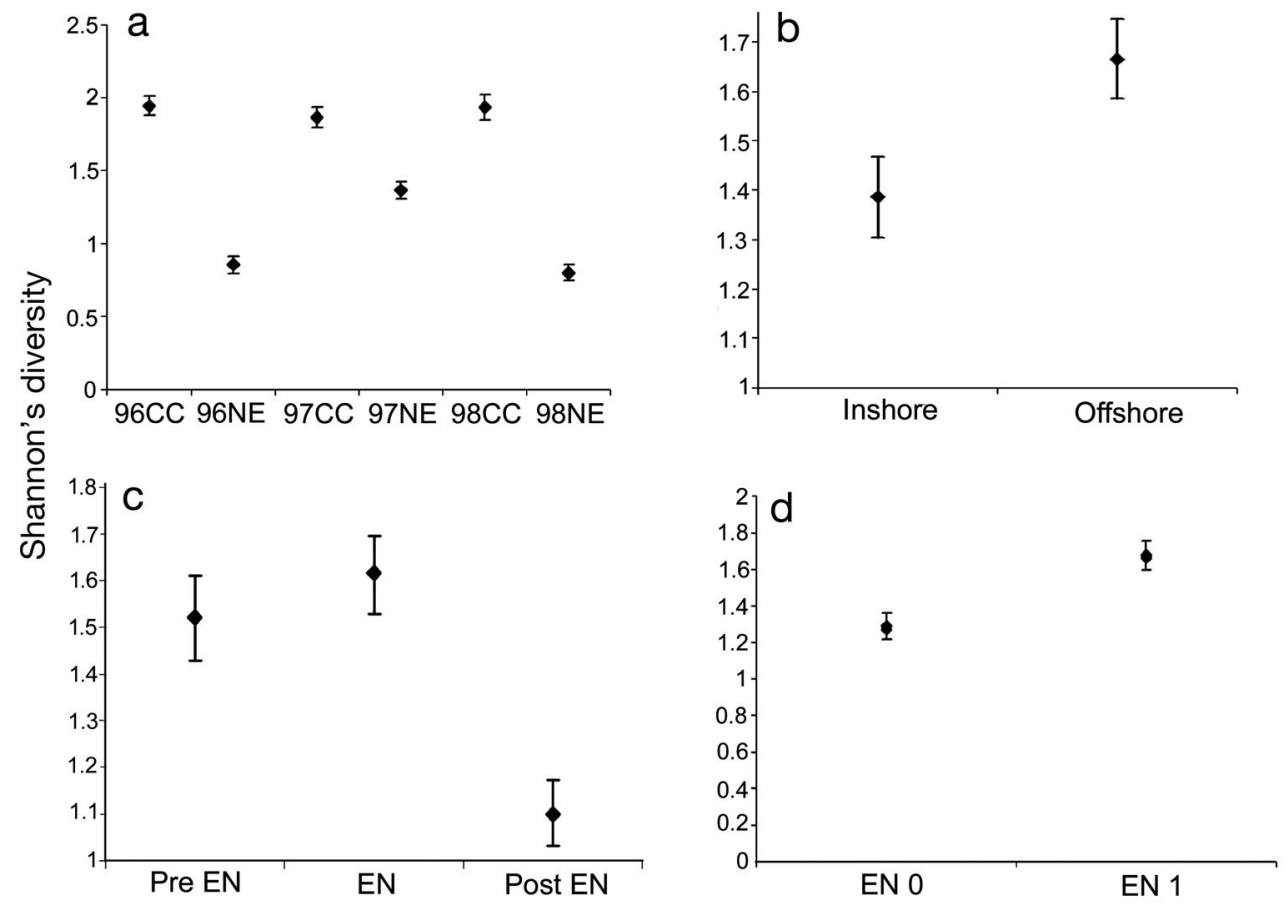

Fig. 7. Shannon diversity based on rarefaction curves. (a) Surveyed CPs; (b) inshore and offshore stations; (c) data from pre-EN (before July 1997), EN, and post-EN; (d) during EN 1 (July 1997 to April 1998) and EN 0 (remaining data) 

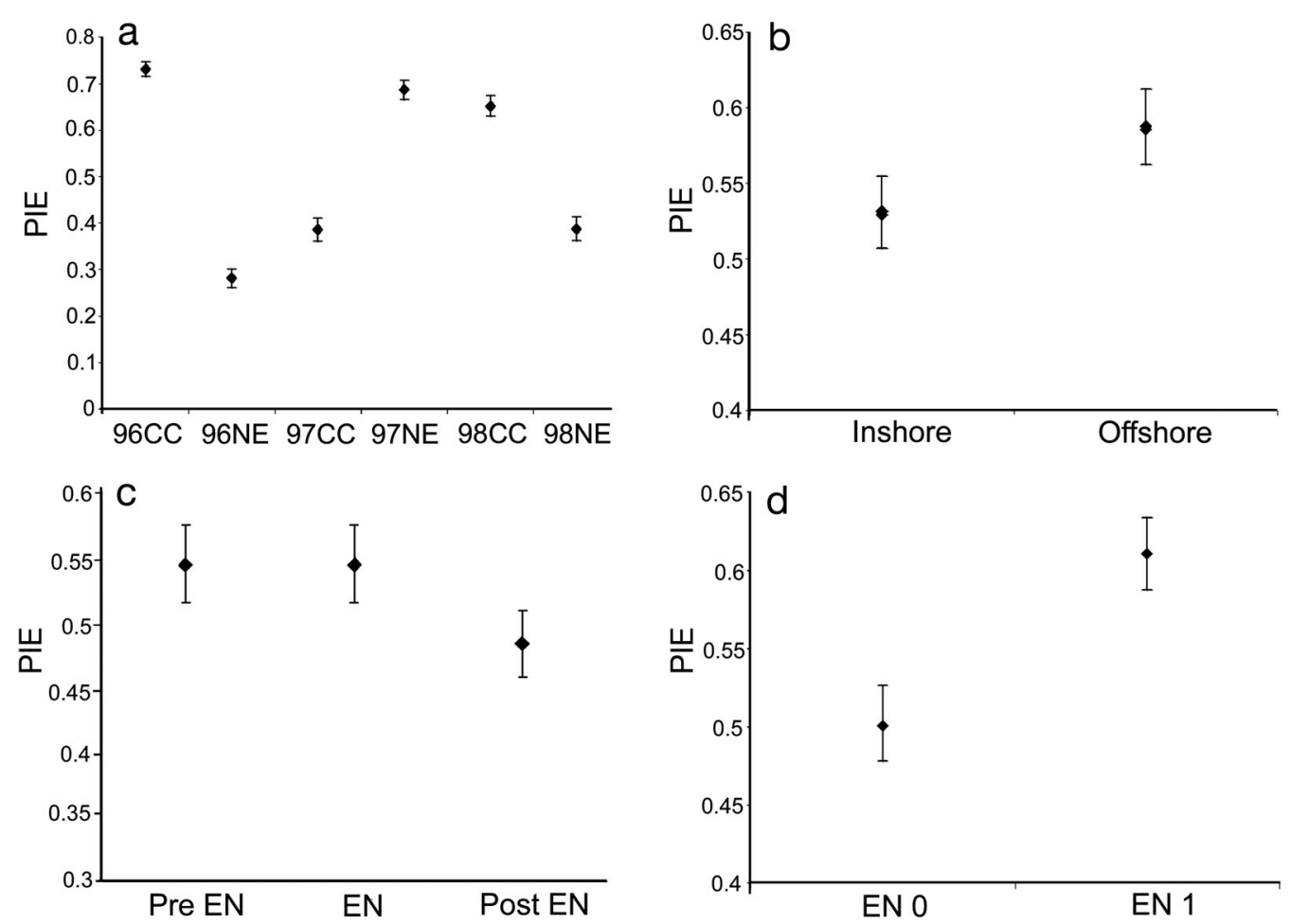

Fig. 8. Evenness based on rarefaction curves. (a) Surveyed CPs; (b) inshore and offshore stations; (c) data from pre-EN (before July 1997), EN, and post-EN; (d) during EN 1 (July 1997 to April 1998) and EN 0 (remaining data). PIE: probability of interspecific encounter

\section{Community analysis}

The nMDS applied to CPs, distance to coast, and EN showed an acceptable fit (stress $=0.14$ ) (Clarke \& Gorley 2006); however, the large number of samples in a single graphic hampered the visual detection of spatial and temporal patterns (Fig. 9a-d). The arrangement of the CP (Fig. 9a) shows dispersion of the samples during the EN influence period. The CP CC group shows a greater similarity. The $98 \mathrm{CC}$ period reflects the full effect of EN in the area and was the most compact group. No inshore-offshore pattern was observed (Fig. 9b), but the preEN, EN, and post-EN periods were well defined (Fig. 9c).

The ANOSIM analysis showed significant differences between the CPs $(R=0.226, p<0.001)$, among the pre-EN, EN, and post-EN samples $(\mathrm{R}=0.069$, $\mathrm{p}<0.001)$, and also based on the distance from the coast $(\mathrm{R}=0.03, \mathrm{p}<0.001)$. The ANOSIM between EN1 (July 1997 to March 1998) and the rest of samples did not show significant differences $(R=-0.102$, $\mathrm{p}=1.00$ ). For all paired analyses of $\mathrm{CP}$, the differences were significant at $\mathrm{p}<0.001$ (except for 96CC and $96 \mathrm{NE}$, for which $\mathrm{p}=0.019$, and for the pair $97 \mathrm{CC}$ and 96NE with $\mathrm{p}=0.012$ ) (Tables 3 to 6 ).
The SIMPER analysis shows that during the CC periods there are more species with low contribution than in the NE period. During the NE period, Hyperioides sibaginis and Lestrigonus bengalensis represented $>90 \%$ of the similarity within groups (Table 3). Also, H. sibaginis and L. bengalensis dominated in all of the studied groups. Other species, such as Tetrathyrus forcipatus, Oxycephalus clausi, Parascelus edwardsi, and L. schizogeneios, contributed mainly to the communities of $\mathrm{CC}$ periods (Table 4).

Fewer species contributed to the NE than to the CC community. The last $3 \mathrm{CPs}$ were similar, with high abundance, although their composition differed. The main feature of CP 98NE, the most dissimilar of the $\mathrm{CPs}$, is that Hyperioides sibaginis and Lestrigonus bengalensis contributed 74.5 and $23.0 \%$, respective$l y$, to their community, and together they dominated, forming $>97 \%$ of the assemblage during that period. $L$. bengalensis contributed more in this period than in the other NE periods.

Unlike other CC periods, the 98CC period had a minor relative contribution of Hyperioides sibaginis; a group of species including Brachyscelus crusculum, Tetrathyrus forcipatus, Parascelus edwardsi, Paralycaea hoylei, Phronima atlantica, and Vibilia armata 

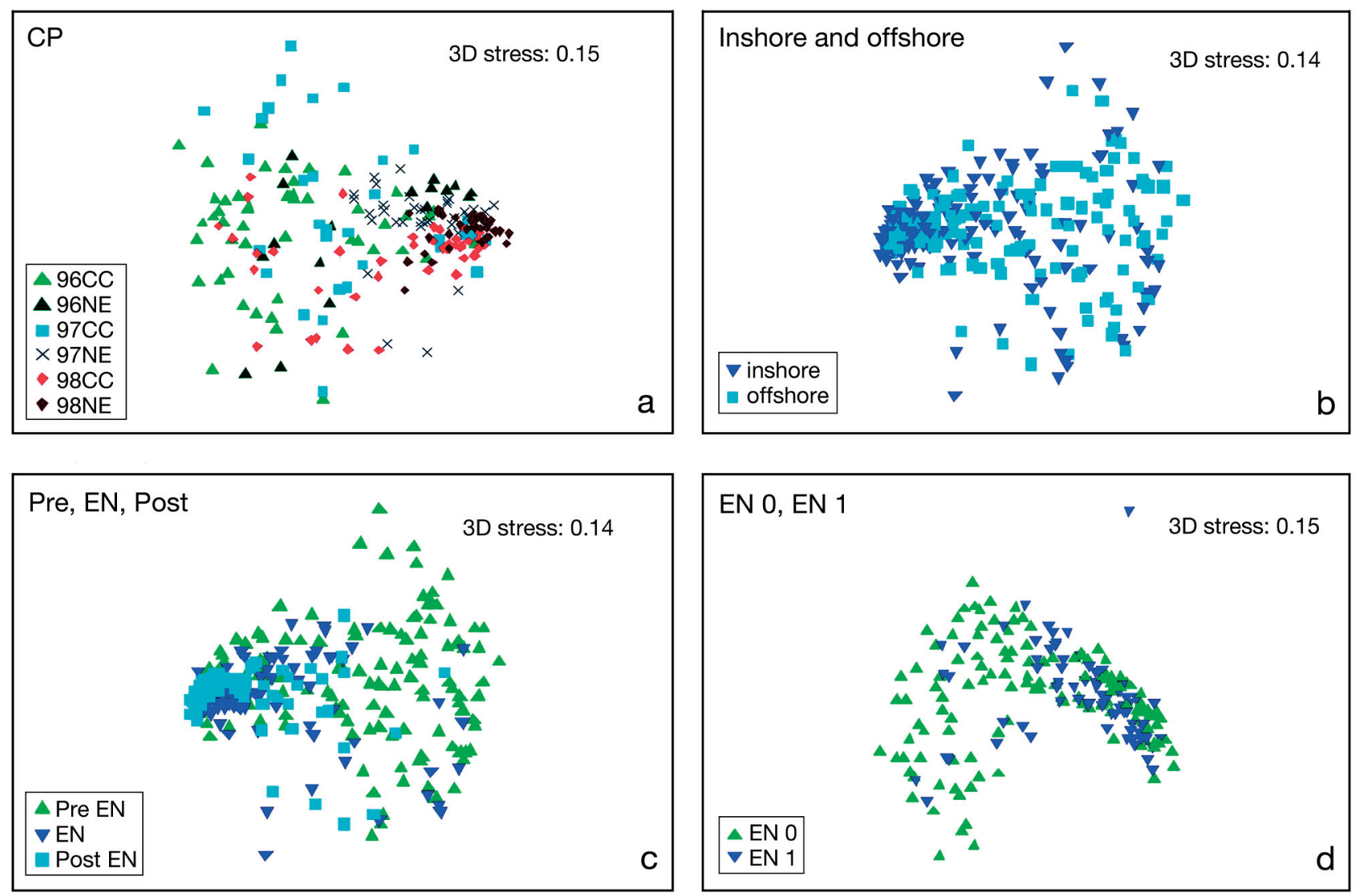

Fig. 9. NMDS graphical analysis of samples collected in the surveyed area (not during June or December). (a) The various climate periods studied; (b) inshore/offshore stations; (c) data pre-EN (before July 1997), during, and post-EN; (d) EN1 (July 1997 to April 1998) and ENO (all others)

Table 3. SIMPER analysis (similarity) of the hyperiid abundances during the climate periods. CC: period dominated by California Current, NE: period dominated by North Equatorial Countercurrent, SP: mean similarity percentage in the group, Av: average abundance (ind. $1000 \mathrm{~m}^{-3}$ ) in the group, \%: mean contribution percentage to similarity. Table shows the group of species contributing $>90 \%$ to similarity in each period

\begin{tabular}{|c|c|c|c|c|c|c|c|c|c|c|c|c|}
\hline \multirow[b]{3}{*}{ Species } & & \multicolumn{6}{|c|}{ Climatic period - } & \multirow{2}{*}{\multicolumn{2}{|c|}{$\begin{array}{l}98 \mathrm{NE} \\
54.04\end{array}$}} \\
\hline & \multicolumn{2}{|c|}{$\begin{array}{l}96 C C \\
15.04\end{array}$} & \multicolumn{2}{|c|}{$\begin{array}{l}96 \mathrm{NE} \\
22.56\end{array}$} & \multicolumn{2}{|c|}{$\begin{array}{l}97 \mathrm{CC} \\
16.61\end{array}$} & \multicolumn{2}{|c|}{$\begin{array}{c}\text { 97NE } \\
39.7\end{array}$} & \multicolumn{2}{|c|}{$\begin{array}{l}98 C C \\
27.35\end{array}$} & & \\
\hline & $\mathrm{Av}$ & $\%$ & $\mathrm{Av}$ & $\%$ & $\mathrm{Av}$ & $\%$ & $\mathrm{Av}$ & $\%$ & $\mathrm{Av}$ & $\%$ & $\mathrm{Av}$ & $\%$ \\
\hline Hyperioides sibaginis & 132 & 36.16 & 271 & 85.04 & 442 & 31.41 & 605 & 87.78 & 758 & 50.48 & 1261 & 74.49 \\
\hline Lestrigonus bengalensis & 61 & 11.26 & 11 & 7.15 & 94 & 12.78 & 76 & 7.21 & 157 & 14.15 & 324 & 23.01 \\
\hline Tetrathyrus forcipatus & 20 & 20.82 & 1 & & 31 & 4.08 & 3 & & 49 & 3.79 & 31 & \\
\hline Oxycephalus clausi & 13 & 10.34 & 4 & & & & & & 9 & & & \\
\hline Brachyscelus crusculum & 5 & 5.72 & 1 & & 8 & & 5 & & 19 & 4.84 & 20 & \\
\hline Lestrigonus schizogeneios & 4 & & 2 & & 39 & 6.35 & 342 & & 28 & 2.00 & 39 & \\
\hline Parascelus edwardsi & 9 & 3.49 & 3 & & 11 & 6.36 & 27 & 5.33 & 26 & 3.78 & 3 & \\
\hline Lestrigonus shoemakeri & 4 & & 6 & & 8 & & 8 & & 41 & 2.42 & 41 & \\
\hline Vibilia longicarpus & 0 & & & & 44 & 17.97 & & & 1 & & 44 & \\
\hline Lycaeopsis zamboangae & 8 & & 1 & & 26 & 7.70 & 14 & & 10 & & 26 & \\
\hline Simorhynchotus antennarius & 4 & 4.65 & 1 & & 3 & & 5 & & 13 & 1.41 & 8 & \\
\hline Euthamneus rostratus & 3 & & & & 55 & 4.26 & & & 0 & & 55 & \\
\hline Paralycaea hoylei & 3 & & 1 & & 4 & & 12 & & 24 & 2.84 & 2 & \\
\hline Phronima atlantica & 0 & & 0 & & 1 & & & & 13 & 2.65 & 1 & \\
\hline Lestrigonus macrophthalmus & 0 & & 0 & & 1 & & 0 & & 22 & 1.72 & 1 & \\
\hline Total & & 92.42 & & 92.19 & & 90.9 & & 93.32 & & 90.09 & & 97.49 \\
\hline
\end{tabular}




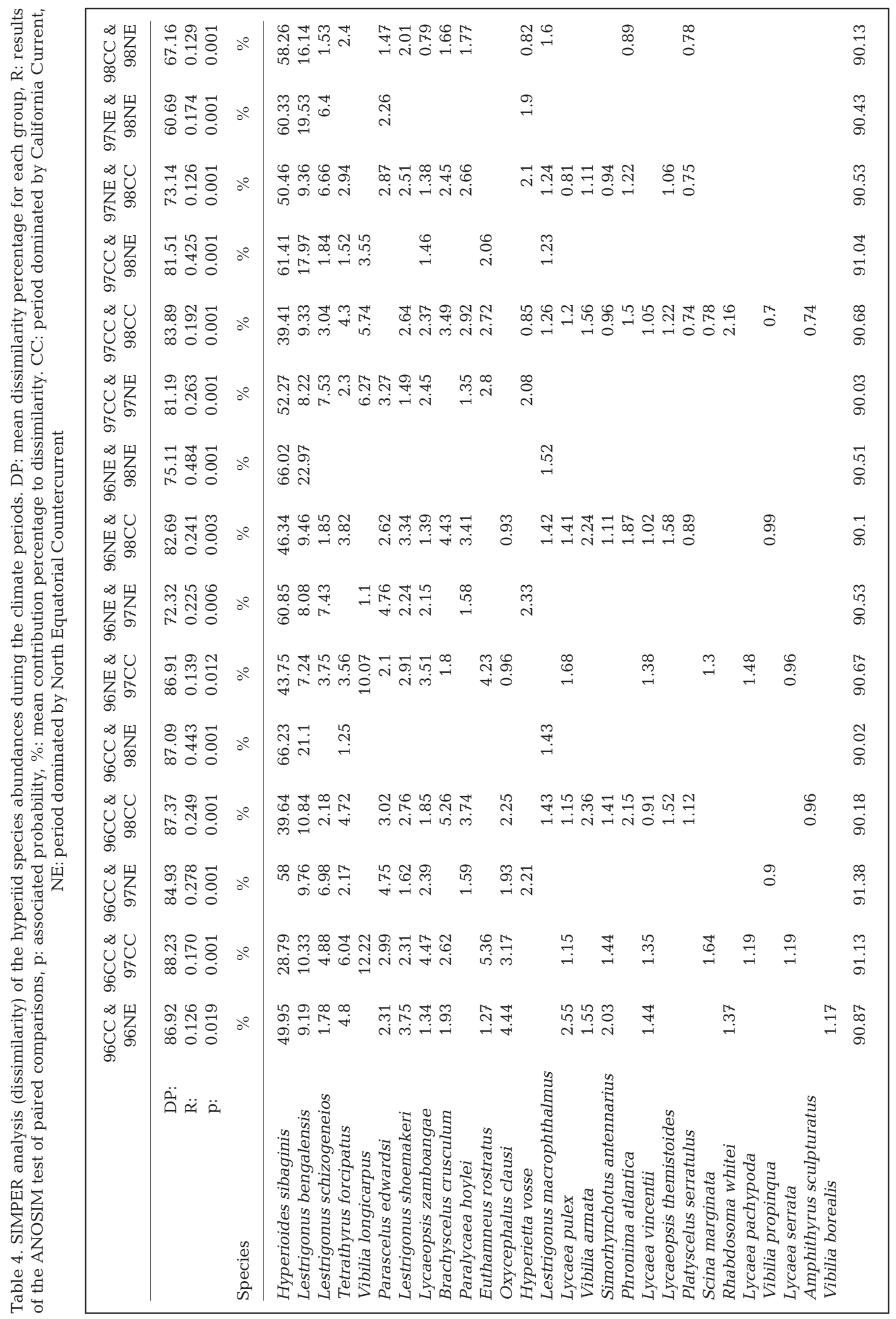


Table 5. SIMPER analysis (similarity and dissimilarity) of the hyperiid species abundances during pre-EN (before July 1997), EN (July 1997 to April 1998), and post-EN periods. Av: average abundance of group, SA: similarity average, DA: dissimilarity average, R: ANOSIM test of paired comparisons, p: associated probability, \%: contribution to group

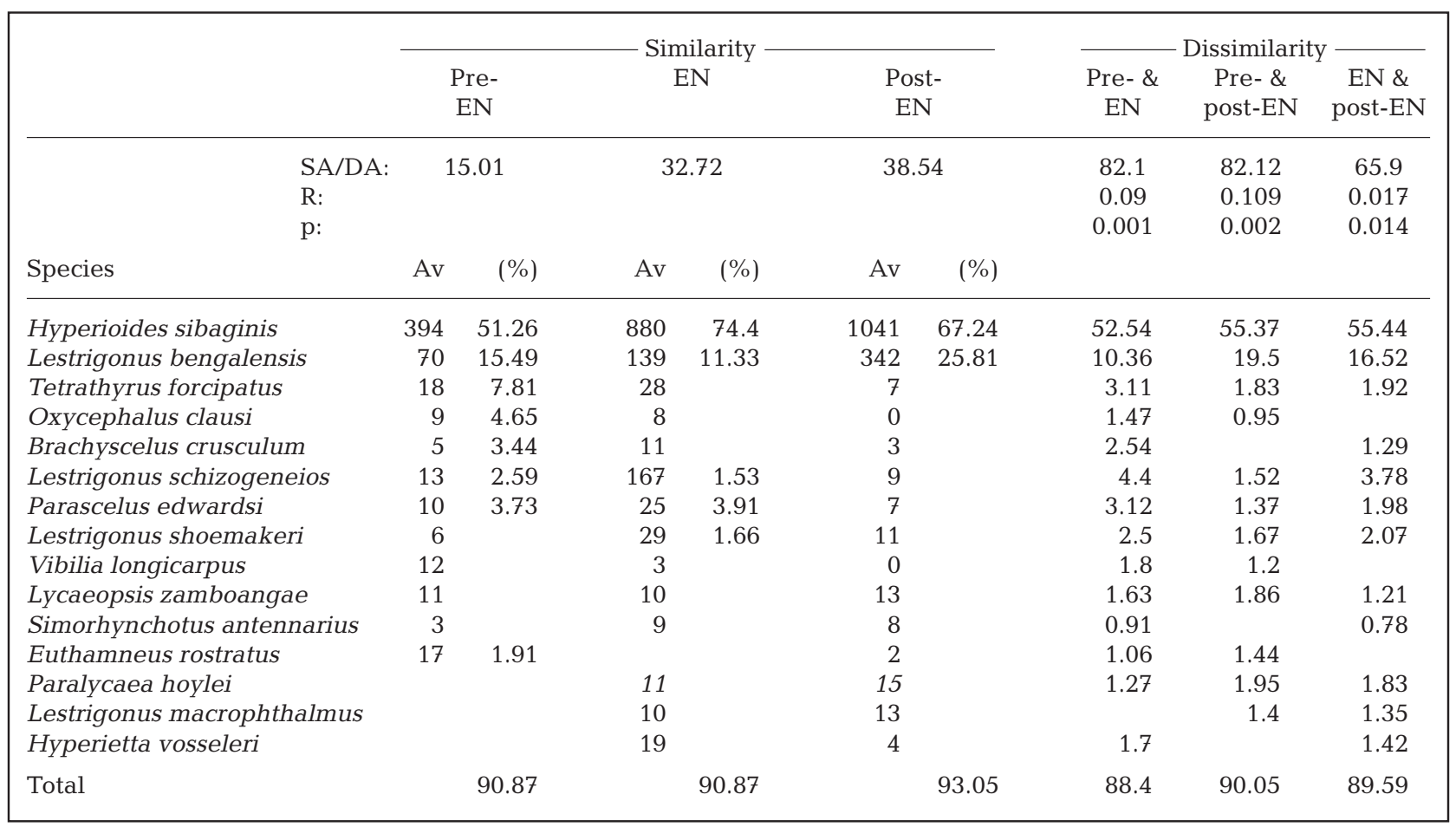

was related to the peak of EN influence (ca. January 1998) (Table 4).

Hyperioides sibaginis and Lestrigonus bengalensis contributed up to $93 \%$ of the similarity during the post-EN period (Table 5). In the pre-EN group, besides $H$. sibaginis, other species (Tetrathyrus forcipatus, Oxycephalus clausi, Parascelus edwardsi, Brachyscelus crusculum, Lestrigonus schizogeneios, and Euthamneus rostratus) marked the group. During EN, P. edwardsi, L. shoemakeri, and L. schizogeneios, in addition to the 2 most abundant species, contributed $>90 \%$ to the group. The EN and post-EN groups were the least dissimilar, but the greater dominance of $H$. sibaginis and $L$. bengalensis and a higher number of species in the post-EN group were the main differences (Table 5).

Up to $90 \%$ of the group at the inshore stations was represented by Hyperioides sibaginis, Lestrigonus bengalensis, and Tetrathyrus forcipatus; the offshore group included the first 2 species as well (Table 6). The dissimilarity analysis showed that the main inshore-offshore difference is that these species are less abundant off the coast.

The redundancy analysis showed 2 almost orthogonal axes representing the temporal variation defined by the multivariable El Niño Index (MEI) and the spa- tial variation defined by the distance of the stations on the coast (Fig. 10). Zooplankton biomass showed a high correlation with the axis of distance from shore. The species associated with EN (high MEI values) were Eupronoe armata, Lycaeopsis themistoides, Amphithyrus sculpturatus, Lestrigonus shoemakeri, Phronimella elongata, Hyperietta vosseleri, and Phronima atlantica. The species related to low MEI values were Lycaea pachypoda, Cranocephalus scleroticus, and Rhabdosoma minor. Both of the patterns of variability, the inter-annual related to the EN event and the seasonal one, were detected (Fig. 10). The group of stations during the EN period was more compact than in the pre-EN period. The greater dispersion of stations on the vertical axis shown during $\mathrm{CC}$ periods suggests a warm-cold periodic variability, which was weak but detectable during 98CC (EN). The Monte Carlo method indicates a significant relationship with environmental variables (Table 6).

\section{DISCUSSION}

The search for understanding of the functional structure of the pelagic ecosystem is currently at the core of modern oceanography. This structure is de- 
termined by physical forces and the associated biological responses (Platt \& Sathyendranath 1999). Our analysis provides evidence showing that the local hyperiid community structure has distinctive features according to distinct hydrographic patterns. It also reveals that these patterns are different from those observed in surrounding areas and diverge from those known for other zooplanktonic taxa.

\section{Species composition}

Previous studies of the hyperiids of Mexico's central Pacific are scarce (Gasca \& Franco-Gordo 2008). It was expected that the monthly collection of samples for 2 yr (1996 to July 1997) would provide a complete account of species in the area. We did not expect the additional increase of species observed after July 1997 in the surveyed area. The addition of almost $30 \%$ of the previous species richness indicates that hyperiids, like other zooplankton, show a sharp increase of tropical-equatorial forms during EN, as was observed for copepods (Lavaniegos et al. 2003, Palomares-García et al. 2003, LópezIbarra \& Palomares-García 2006) and salps (Hereu et

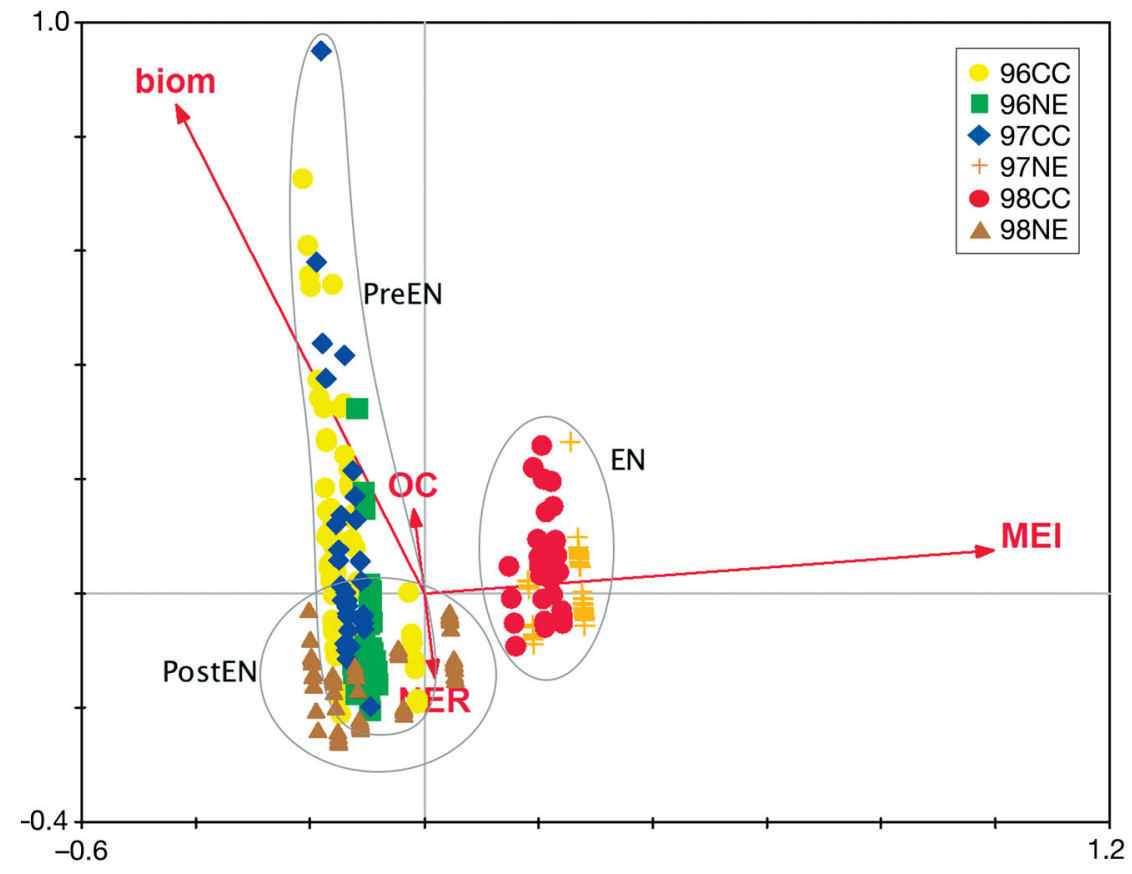

Fig. 10. Ordination pattern of temporal variation from the redundancy analysis
Table 6. SIMPER analysis (similarity and dissimilarity) of the hyperiid species abundances at inshore and offshore stations during the surveyed period. Av: average abundance of group, \%: contribution to group, SA: similarity average, DA: dissimilarity average

\begin{tabular}{|c|c|c|c|c|c|}
\hline & \multicolumn{4}{|c|}{ Similarity } & \multirow{2}{*}{$\begin{array}{c}\text { Dissimilarity } \\
\text { Inshore } \\
\text { vs. offshore }\end{array}$} \\
\hline & \multicolumn{2}{|c|}{ Inshore } & \multicolumn{2}{|c|}{ Offshore } & \\
\hline \multirow[t]{2}{*}{ SA/DA (\%) } & \multicolumn{2}{|c|}{24.43} & \multicolumn{2}{|c|}{21.11} & 78.21 \\
\hline & Av & $\%$ & Av & $\%$ & \\
\hline Hyperioides sibaginis & 948 & 73.39 & 458 & 58.14 & 51.75 \\
\hline Lestrigonus bengalensis & 191 & 14.66 & 117 & 19.94 & 13.79 \\
\hline Tetrathyrus forcipatus & 26 & 3.06 & 11 & & 3.26 \\
\hline Oxycephalus clausi & 9 & & 5 & & 1.78 \\
\hline Brachyscelus crusculum & 7 & & 6 & 2.09 & 1.8 \\
\hline Lestrigonus schizogeneios & 108 & & 13 & 2.49 & 3.51 \\
\hline Parascelus edwardsi & 15 & & 13 & 3.44 & 2.31 \\
\hline Lestrigonus shoemakeri & 12 & & 17 & 2.17 & 2.21 \\
\hline Vibilia longicarpus & 7 & & 5 & & 2.12 \\
\hline Lycaeopsis zamboangae & 10 & & 12 & 2.68 & 1.73 \\
\hline Euthamneus rostratus & 13 & & 3 & & 1.55 \\
\hline Total & & 91.11 & & 90.95 & 85.81 \\
\hline
\end{tabular}

al. 2006). Furthermore, considering the 56 species known before the onset of EN and the 24 recorded after July 1997, the increase was $43 \%$ (Table 2) (Gasca 2009a, Gasca et al. 2010).

The 84 species recognized in tropical areas of the Pacific coast of Mexico, south of Baja California, i.e. 80 in this study plus Vibilia pyripes, $V$. australis, $V$. cultripes, and $V$. stebbingi, recorded by Shih \& Hendrycks (2003), represent $\sim 50 \%$ of all known species in the tropical Pacific (Vinogradov 1991). This figure is comparable to that of other subregions of the Pacific (Vinogradov 1991: 119 species; Shulenberger 1977: 83 species). However, $>200$ species have been found to occur in the Pacific Ocean (Shih \& Cheng 1995, Vinogradov et al. 1996), and regional lists should grow when deeper waters are sampled (Gasca 2009b).

\section{Abundance}

A group of species including Phronima atlantica, Phronimella elongata, Phrosina semilunata, and some species of Primno was proposed by Vinogradov (1999) as being among the 
most abundant species in the Pacific. However, data from different regions, such as the eastern South Pacific Gyre (Vinogradov 1991), the Gulf of California (Siegel-Causey 1982) and the CC area off Baja California (Lavaniegos \& Hereu 2009), suggest a different trend. In the study area and in other tropical Pacific regions, Hyperioides sibaginis and Lestrigonus bengalensis were the most abundant (Gasca \& Franco-Gordo 2008, Zeidler 1984, Valencia \& Giraldo 2009). In general, each area of the Eastern Pacific with different oceanographic features can be characterized by a defined group of most abundant species.

The hyperiid fauna of the Mexican tropical Pacific resembles that of the Gulf of California but clearly differs from that of the CC. None of the 4 most common species in the surveyed area are among the predominant forms in the California region (Brusca 1981, Lavaniegos \& Ohman 1999). This suggests that the presumed CC influence was not detected in the local hyperiid fauna even during the CC periods. However, the increase in the number of species in the CC periods shows the arrival of species from other subregions.

The overall average abundance of hyperiids in the study area (1070 ind. $1000 \mathrm{~m}^{-3}$ ) was similar to that found in the adjacent Banderas Bay (1167 ind. $1000 \mathrm{~m}^{-3}$ in September) (Gasca \& Franco-Gordo 2008) and is comparable to values reported in other areas, like the North Pacific Central Gyre (1 to 3695 ind. $400 \mathrm{~m}^{-3}$ ) or adjacent areas of the Atlantic such as the Gulf of Mexico (1437 ind. $1000 \mathrm{~m}^{-3}$ ) (Gasca 2004), but is higher than those found in oligotrophic waters of the Caribbean (240 ind. $1000 \mathrm{~m}^{-3}$ ) (Gasca \& Suárez-Morales 2004).

Hyperiid abundance was relatively low during 1996, and the local community structure was characterized by the dominance of Hyperioides sibaginis and Lestrigonus bengalensis. The progressive increase in the abundance of hyperiids from the beginning to the end of the sampling period, as shown by the average of the different CP (Fig. 2a), was unexpected. It is possible that it resulted from the addition of populations of different origins or the influence of EN. The influence of the cold (CC) and warm (NE) conditions in the area was clear, with lower abundances during the cold periods than in the warm ones, a pattern that remained even during the EN year. The only CPs in which no differences in abundance occurred were $97 \mathrm{NE}$ and $98 \mathrm{CC}$, both during EN. Hence, the hyperiid abundance could be considered as a local indicator of EN. Furthermore, even greater abundances were recorded in the following months, suggesting that EN may trigger or favor higher reproductive rates of the dominant species for a longer period.

Quite unexpectedly, hyperiids were more abundant during the EN than during the previous years. EN has been commonly associated with a relatively low zooplankton productivity and abundance (Barber \& Chavez 1983, Roemmich \& McGowan 1995, Franco-Gordo et al. 2001a,b, 2004). Locally, this effect could be explained by an increase in the reproduction of the dominant hyperiid species and possibly by the addition of populations of different origins resulting from the local convergence of distinct water masses.

The 4 most abundant species in this study (Hyperioides sibaginis, Lestrigonus bengalensis, L. schizogeneios, and Tetrathyrus forcipatus) were the same throughout the study period. The other species showed 2 patterns: (1) occurring or being more frequent during EN (e.g. Paralycaea gracilis, Eupronoe armata, Anchylomera blossevillei, and Phronimella elongata) and (2) absent or decreasing in frequency during EN (e.g. Scina marginata, T. forcipatus, Cranocephalus scleroticus, Rhabdosoma minor, and Lycaea pachypoda); these species were also absent when warm waters prevailed in the area.

\section{Diversity}

Sequential changes in richness were evident and related to the arrival of warmer waters (PESW) resulting from the influence of EN. The number of species was significantly lower during the first half of the study than in the second (Fig. 5). During the study period, the temporal monitoring of the species richness allowed the detection of changes that may be associated with variations of the hydrographic conditions. Unexpectedly, richness values in the CC CPs were higher than during the warm (NE) periods, but an even greater richness value was recorded in CC 1998; this could be due to the addition of the PEW fauna arriving with EN. Lavaniegos \& Ohman (1999) observed a different pattern in the CC off southern California; they observed that the years with fewer species were 1995 and 1997, although in 1972 (another EN year), they also recorded more species. The finding of greater richness during EN (vs. pre- and post-EN) and EN-related CPs indicates the strong influences of this event on the expected number of species.

Greater diversity values in CC than in NECC periods are explained by the combination of the following factors: (1) the high number of species found in $\mathrm{CP}$ CC, (2) their low dominance, (3) the arrival of 
water from the north and east adding to the local fauna, and (4) reduced dominance of the 2 most abundant species in the area. The greater diversity observed in the $97 \mathrm{NE}$ period resulted from a higher evenness value. The high diversity found in EN1 is related to the higher number of species found in that period. In contrast, the post-EN low diversity results from the high dominance of Hyperioides sibaginis and Lestrigonus bengalensis in that period; these species were favored by the warm conditions associated with EN.

\section{Evenness}

The mixing of water masses during the $\mathrm{CC}$ and $\mathrm{EN}$ periods was favorable for higher values of evenness and characterized the convergence of waters in the area. The arrival of warm water fauna weakened the dominance of some species, as observed in other NECC periods. That is, at the onset of EN, the NECC hyperiid community is more similar to that influenced by the $\mathrm{CC}$ influence (with higher diversity and lower dominance).

\section{Analysis of the hyperiid community}

The ANOSIM revealed CP- and EN-related communities and also inshore and offshore communities in an area where the continental shelf is very narrow. There is a defined community structure related to EN (EN1: July 1997 to March 1998). The SIMPER analysis allowed us to define the structure of each of the communities tested (Tables 3 to 6 ).

As found in our survey, the known biological consequences of EN in the zooplankton include changes in species composition (Gómez-Gutiérrez et al. 1995, González et al. 2000, Lavaniegos \& Ohman 1999). Also, biomass may increase (Brodeur \& Ware 1992), decrease (Roemmich \& McGowan 1995), or remain stable (Lavaniegos \& Ohman 1999), depending on the area and the group surveyed (Fiedler 2002). The impoverishment of the pelagic environment as an effect of EN has also been described for zooplankton and ichthyoplankton taxa in the eastern Pacific (Chavez et al. 1999, Franco-Gordo et al. 2004); however, the local hyperiid community showed a reverse pattern (e.g. higher abundances and diversity). This may be related to the biology of some of the species that use other organisms (gelatinous zooplankton) for their sustainment and thus do not depend entirely on the availability of food in the environment.
Franco-Gordo et al. (2004) found local inter-annual variations of the zooplankton biomass and the ichthyoplankton related to EN (e.g. less abundance and diversity). They also detected a response of the fish larvae community to seasonal cycles related to hydrographic and climatic conditions. As reported herein, hyperiids showed a seasonal variation resulting from the influence of EN, but with an opposite pattern. Under the influence of the CC, fish larvae and biomass showed a greater abundance and a reduced diversity and evenness, whereas during EN, the abundance and diversity were lower.

During the onset of EN, the biological production and dynamics changed in coastal areas of the CC system and other areas of the Eastern Tropical Pacific (Morales-Ramírez \& Brugnoli-Olivera 2001, Lavaniegos et al. 2002). Conditions returned to normality in the aftermath. A similar response, with a delay of 1 to 2 mo, was observed in the tropical Pacific (Chavez et al. 1998, 1999), suggesting that the influence of EN in the regional biota is detectable at the initial but not at the final stages. This is true for the local hyperiid community, whose return to pre-EN conditions was not observed. Our results suggest that the residual effects of EN on the hyperiid community continued for several months after the oceanographic end of EN. This inertial response has not been described previously and is evidence of the wide variety of potential responses that different zooplankton taxa may present as part of this complex pelagic community. It is necessary to study the biological-physical coupling of different zooplankton groups in the area during EN to fully understand the effects of this event in the community.

Acknowledgements. This work is part of the doctoral thesis presented by R.G. in the postgraduate program of the Universidad de Guadalajara. Funding for fieldwork and general logistic support was provided by CUCSUR, Universidad de Guadalajara. We thank the crew of the R/V 'BIP-V' for their help and guidance during these years of sampling. We received assistance from numerous persons in the many years of fieldwork; we sincerely thank them all. G. González-Sansón provided useful comments to improve the statistical analyses presented in this work. A database of the information presented herein was prepared with the aid of CONABIO project DJo24.

\section{LITERATURE CITED}

Aguirre-Gómez R, Salmerón O, Álvarez R (2003) Effects of ENSO off the southwest coast of Mexico, 1996-1999. Geofis Int 42:377-388

Badán-Dangón ARF (2003) The effects of El Niño in Mexico: a survey. Geofís Int 42:1-3

Barber RT, Chavez FP (1983) Biological consequences of El Niño. Science 222:1203-1210 
Bary BM (1959a) Species of zooplankton as a means of identifying different surface waters and demonstrating their movements and mixing. Pac Sci 13:14-54

Bary BM (1959b) Ecology and distribution of some pelagic Hyperiidea (Crustacea: Amphipoda) from New Zealand waters. Pac Sci 13:317-334

Brodeur RD, Ware DM (1992) Long-term variability in zooplankton biomass in the subarctic Pacific Ocean. Fish Oceanogr 1:32-38

Brusca GJ (1967) The ecology of pelagic amphipods. I. Species accounts, vertical zonation and migration of amphipods from the waters off southern California. Pac Sci 21: 382-393

Brusca GJ (1981) Annotated keys to the Hyperiidea (Crustacea: Amphipoda) of North American coastal waters. Allan Hancock Found Tech Rep 5:1-76

Brusca RC, Hendrickx ME (2005) Crustacea 4. Peracarida: Lophogastrida, Mysida, Amphipoda, Tanaidacea and Cumacea. In: Hendrickx ME, Brusca RC, Findley LT (eds) A distributional checklist of the macrofauna of the Gulf of California, Mexico. Part I. Invertebrates. ArizonaSonora Desert Museum, Tucson, AZ, p 147-154

> Chavez FP, Strutton PG, McPhaden MJ (1998) Biologicalphysical coupling in the central equatorial Pacific during the onset of the 1997-98 El Niño. Geophys Res Lett 25: 3543-3546

> Chavez FP, Strutton PG, Friederich GE, Feely RA, Feldman GC, Foley DG, McPhaden MJ (1999) Biological and chemical response of the equatorial Pacific Ocean to the 1997-98 El Niño. Science 286:2126-2131

Clarke KR (1993) Non-parametric multivariate analyses of changes in community structure. Aust J Ecol 18:117-143

Clarke KR, Gorley RN (2006) PRIMER v6: user manual/tutorial. PRIMER-E, Plymouth

Clarke KR, Warwick RM (2001) Change in marine communities: an approach to statistical analysis and interpretation, 2nd edn. PRIMER-E, Plymouth

> Clarke KR, Somerfield PJ, Chapman MG (2006) On resemblance measures for ecological studies, including taxonomic dissimilarities and zero-adjusted Bray-Curtis coefficient for denuded assemblages. J Exp Mar Biol Ecol 330:55-80

> Fiedler PC (2002) Environmental change in the eastern tropical Pacific Ocean: review of ENSO and decadal variability. Mar Ecol Prog Ser 244:265-283

Filonov A, Tereshchenko I (2000) El Niño 1997-98 monitoring in mixed layer at the Pacific Ocean near Mexico's west coast. Geophys Res Lett 27:705-707

Filonov A, Tereshchenko IE (2010) El régimen termodinámico en la costa de los estados de Jalisco y Colima. In: Godínez-Domínguez E, Franco-Gordo MC, Rojo-Vázquez JA, Silva-Bátiz FA, González Sansón G (eds) Ecosistemas marinos de la Costa Sur de Jalisco y Colima Universidad de Guadalajara, Autlán de Navarro, México, p 29-72

> Franco-Gordo C, Godínez-Domínguez E, Suárez-Morales E (2001a) Zooplankton biomass variability in the Mexican Eastern Tropical Pacific. Pac Sci 55:191-202

Franco-Gordo C, Suárez-Morales E, Godínez-Domínguez E, Flores R (2001b) A seasonal survey of the fish larvae community of the central Pacific coast of Mexico. Bull Mar Sci 68:383-396

Franco-Gordo C, Godínez-Domínguez E, Filonov AE, Tereshchenko IE, Freire J (2004) Plankton biomass and larval fish abundance prior to and during the El Niño period of 1997-1998 along the Central Pacific coast of México. Prog Oceanogr 63:99-123

- Gasca R (2004) Distribution and abundance of hyperiid amphipods in relation to summer mesoscale features in the southern Gulf of Mexico. J Plankton Res 26:993-1003

Gasca R (2009a) Hyperiid amphipods (Crustacea: Peracarida) in Mexican waters of the Pacific Ocean. Pac Sci 63:83-95

Gasca R (2009b) Diversity of hyperiid amphipods (Crustacea: Peracarida) in the Western Caribbean Sea: news from the deep. Zool Stud 48:63-70

> Gasca R, Franco-Gordo C (2008) Hyperiid amphipods (Peracarida) from Banderas Bay, Mexican Tropical Pacific. Crustaceana 81:563-575

> Gasca R, Haddock SHD (2004) Associations between gelatinous zooplankton and hyperiid amphipods (Crustacea: Peracarida) in the Gulf of California. Hydrobiologia 530-531:529-535

Gasca R, Suárez-Morales E (2004) Distribution and abundance of hyperiid amphipods (Crustacea: Peracarida) from the Mexican Caribbean Sea, (August 1986). Caribb J Sci 40:23-30

> Gasca R, Suárez-Morales E, Franco-Gordo C (2010) New records of hyperiids (Amphipoda, Hyperiidea) from surface waters of the central Mexican Pacific. Crustaceana 83:927-940

> Gómez-Gutiérrez J, Palomares-García R, Gendron D (1995) Community structure of the euphausiid populations along the west coast of Baja California, Mexico, during the weak ENSO 1986-1987. Mar Ecol Prog Ser 120:41-51

González HE, Sobarzo M, Figueroa D, Nöthig EM (2000) Composition, biomass and potential grazing impact of the crustacean and pelagic tunicates in the northern Humboldt Current area off Chile: differences between El Niño and non-El Niño years. Mar Ecol Prog Ser 195: 201-220

Gotelli NJ, Entsminger GL (2009) EcoSim: null modelling software for ecologists, Version 7. Acquired Intelligence \& Kesey-Bear, Jericho, VT, http://garyentsminger.com/ ecosim/

Gotelli NJ, Graves GR (1996) Null models in ecology. Smithsonian Institution Press, Washington DC

Harbison GR, Madin LP (1976) Description of the female Lycaea nasuta Claus, 1879 with an illustrated key to the species of Lycaea Dana, 1852 (Amphipoda, Hyperiidea). Bull Mar Sci 26:165-171

Hereu CM, Lavaniegos BE, Gaxiola-Castro G, Ohman MD (2006) Composition and potential grazing impact of salp assemblages off Baja California during the 1997-1999 El Niño and La Niña. Mar Ecol Prog Ser 318:123-140

> Hurlbert SH (1971) The nonconcept of species diversity: a critique and alternative parameters. Ecology 52:577-585

Kane JE (1962) Amphipoda from waters south of New Zealand. N Z J Sci 5:295-310

> Kessler WS (2006) The circulation of the Eastern Tropical Pacific: a review. Prog Oceanogr 69:181-217

Lavaniegos BE, Hereu C (2009) Seasonal variation in hyperiid amphipod abundance and diversity and influence of mesoscale structures off Baja California. Mar Ecol Prog Ser 394:137-152

Lavaniegos BE, Ohman MD (1999) Hyperiid amphipods as indicators of climate change in the California Current. In: Schram FR, von Vaupel Klein JC (eds) Crustaceans and the biodiversity crisis. Proc 4 th Int Crustacean Congress. Brill, Leiden, p 489-509 
Lavaniegos BE, Jiménez-Pérez LC, Gaxiola-Castro G (2002) Plankton response to El Niño 1997-1998 and La Niña 1999 in the southern region of the California Current. Prog Oceanogr 54:33-58

Lavaniegos BE, Gaxiola-Castro G, Jiménez-Pérez LC, González-Esparza MR, Baumgartner T, García-Córdova J (2003) 1997-98 El Niño effects on the pelagic ecosystem of the California current off Baja California, Mexico. Geofís Int 42:483-494

Leps J, Smilauer P (2007) Multivariate analysis of ecological data using CANOCO. Cambridge University Press, Cambridge

Longhurst AR (2006) Ecological geography of the sea, 2nd edn. Elsevier, Amsterdam

López-Ibarra GA, Palomares-García R (2006) Estructura de la comunidad de copépodos en Bahía Magdalena, México, durante El Niño 1997-1998. Rev Biol Mar Oceanogr 41:63-76

Marinovic BB, Croll DA, Gong N, Benson SR, Chavez FP (2002) Effects of the 1997-1999 El Nino and La Nina events on zooplankton abundance and euphausiid community composition within the Monterey Bay coastal upwelling system. Prog Oceanogr 54:265-277

Morales-Ramírez A, Brugnoli-Olivera E (2001) El Niño 1997 1998 impact on the plankton dynamics in the Gulf of Nicoya, Pacific coast of Costa Rica. Rev Biol Trop 49: 103-114

Palomares-García R, Martínez-López A, De Silva-Dávila R, Funes-Rodríguez R and others (2003) Biological effects of El Niño 1997-98 on a shallow subtropical ecosystem: Bahía Magdalena, Mexico. Geofis Int 42:455-466

Peterson WT, Keister JE (2002) The effect of a large cape on distribution patterns of coastal and oceanic copepods off Oregon and northern California during the 1998-1999 El Niño-La Niña. Prog Oceanogr 53:389-411

Platt T, Sathyendranath S (1999) Spatial structure of pelagic ecosystem processes in the global ocean. Ecosystems 2: 384-394

Roemmich D, McGowan J (1995) Climatic warming and the decline of zooplankton in the California Current. Science 267:1324-1326

Shih Ct (1991) Description of two new species of Phronima Latreille, 1802 (Amphipoda: Hyperiidea) with a key to all species of the genus. J Crustac Biol 11:322-335

Shih Ct, Cheng QC (1995) Zooplankton of China seas (2). The Hyperiidea (Crustacea: Amphipoda). China Ocean Press, Beijing

Shih Ct, Hendrycks EA (2003) A new species and new records of the genus Vibilia Milne Edwards, 1830 (amphipoda: Hyperiidea: Vibiliidae) occurring in the eastern Pacific Ocean. J Nat Hist 37:253-296

Shulenberger E (1977) Hyperiid amphipods from the zoo-

Editorial responsibility: Hans Heinrich Janssen,

Oldendorf/Luhe, Germany plankton community of the North Pacific central gyre. Mar Biol 42:375-385

Siegel-Causey D (1982) Factors determining the distribution of hyperiid Amphipoda in the Gulf of California. PhD dissertation, University of Arizona, Tucson

Smith PE, Richardson SL (1977) Standard techniques for pelagic fish egg and larvae surveys. FAO Fish Tech Pap 175

Sokal RR, Rohlf FJ (1995) Biometry, 3rd edn. Freeman, New York, NY

ter Braak CJF, Smilauer P (1998) CANOCO reference manual and user's guide to CANOCO for windows: software for canonical community ordination (version 4). Microcomputer Power, Ithaca, New York, NY

Trasviña A, Barton ED (2008) Summer circulation in the Mexican tropical Pacific. Deep-Sea Res I 55:587-607

Trasviña A, Lluch-Cota D, Filonov AE, Gallegos A (1999) Oceanografía y El Niño. In: Magaña V (ed) Los impactos del Niño en México. Cap 3, UNAM, México, p 69-101

> Trenberth KE (1997) The definition of El Niño. Bull Am Meteorol Soc 78:2771-2777

> Valencia B, Giraldo A (2009) Hipéridos (Crustacea: Amphipoda) en el sector norte del Pacífico oriental tropical colombiano. Lat Am J Aquat Res 37:265-273 (in Spanish with English abstract)

Vinogradov GM (1991) Hyperiid amphipods in the eastern part of the South Pacific gyre. Mar Biol 109:259-265

Vinogradov GM (1999) Amphipoda. In: Boltovskoy D (ed) South Atlantic zooplankton. Backhuys Publishers, Leiden, p 1141-1240

Vinogradov ME, Volkov AF, Semenova TN (1996) Hyperiid amphipods (Amphipoda, Hyperiidea) of the world oceans. Science Publishers, Lebanon, NH

Wolter K, Timlin MS (1998) Measuring the strength of ENSO events: How does 1997-1998 rank? Weather 153:315-324

Zeidler W (1984) Distribution and abundance of some Hyperiidea (Crustacea: Amphipoda) in Northern Queensland waters. Aust J Mar Freshwater Res 35:285-305

Zeidler W (2003) A review of the hyperiidean amphipod superfamily Vibilioidea Bowman and Gruner, 1973 (Crustacea: Amphipoda: Hyperiidea). Zootaxa 280:1-104

Zeidler W (2004a) A review of the hyperiidean amphipod superfamily Lycaepsoidea Bowman and Gruner, 1973 (Crustacea: Amphipoda: Hyperiidea). Zootaxa 520:1-184

Zeidler W (2004b) A review of the families and genera of the hyperiidean amphipod superfamily Phronimoidea Bowman and Gruner, 1973 (Crustacea: Amphipoda: Hyperiidea). Zootaxa 567:1-66

Zeidler W (2006) A review of the hyperiidean amphipod superfamily Archaeoscinoidea Vinogradov, Volkov and Semenova, 1982 (Crustacea: Amphipoda: Hyperiidea). Zootaxa 1125:1-37

Submitted: September 27, 2011; Accepted: December 21, 2011 Proofs received from author(s): May 15, 2012 